\title{
The Appearance of NPY and VIP in Sympathetic Neuroblasts and Subsequent Alterations in Their Expression
}

\author{
Sophia Tyrrell and Story C. Landis \\ Department of Neurosciences, Case Western Reserve University School of Medicine, Cleveland, Ohio 44106
}

Mature sympathetic neurons contain one or more neuropeptides in addition to a classical neurotransmitter. We compared the development of two peptides, neuropeptide Y (NPY) and vasoactive intestinal peptide (VIP), in rat superior cervical (SCG) and stellate ganglia. NPY immunoreactivity (-IR) was first detected at embryonic day (E)12.5. It was of similar immunofluorescence intensity in almost all tyrosine hydroxylase (TH)-IR cells. In contrast, VIP-IR, of variable fluorescence intensity, appeared at E14.5 in a subset of TH-IR cells in the stellate ganglion but not in SCG. Both peptides were present in bromodeoxyuridine-labeled neuronal precursors as well as neurons. The intensity of NPY immunofluorescence increased until E16.5. Subsequently, while it continued to increase in some neurons, the intensity decreased in others so that at birth approximately $55 \%$ of SCG and stellate neurons were NPY-IR. Developmental changes in NPY concentration, determined by radioimmunoassay, were similar in both ganglia, increasing between E14.5 and E16.5 and then decreasing $60 \%$ between E16.5 and birth. VIP expression differed from that of NPY. The proportion of VIP-IR cells began to decrease the day after VIP-IR was first detected. Although VIP-IR was present in one-third of E14.5 TH-IR stellate cells, at birth only $2 \%$ were VIP-IR. VIP-IR, measured by radioimmunoassay, was uniformly severalfold more concentrated in the stellate than SCG, and its concentration decreased throughout embryonic development, $40 \%$ between $\mathrm{E} 14.5$ and $\mathrm{E} 16.5$ and $95 \%$ by birth. In situhybridization revealed detectable mRNA for both NPY and VIP at E14.5 in stellate ganglion and mRNA for NPY, but not VIP, in SCG. Initially, ganglionic neuropeptide mRNA appeared uniformly distributed but became heterogeneous. Our data indicate that features of the diverse peptidergic phenotypes expressed by sympathetic neurons are present when peptides are first detected while others arise subsequently. The final acquisition of peptidergic phenotypic diversity is complex, entailing both early induction in many cells and subsequent restriction to specific subpopulations.

\footnotetext{
Received Oct. 21, 1993; revised Jan. 25, 1994; accepted Feb. 8, 1994.

We are indebted to a number of our colleagues for their assistance: Yi Sun and Dr. Annette Shadiak with the RIAs, Dr. Ruth Siegel and Laurie Garner with the in situ hybridization, Drs. Richard Wagner and Said Amini with statistical analyses, and Carolyn Marks for manuscript preparation. We would also like to thank Drs. Alison Hall, Paul Henion, Mahendra Rao, Ruth Siegel, and Richard Zigmond for useful insights in numerous discussions and Drs. Alison Hall, Ruth Siegel, and Richard Zigmond for thoughtfully reading and commenting on the manuscript. These studies were supported by HD 25681.

Correspondence should be addressed to Dr. Story C. Landis at the above address. Copyright (C) 1994 Society for Neuroscience 0270-6474/94/144529-19\$05.00/0
}

IKey words: neural crest, autonomic neurons, transmitter phenotype, neuropeptide expression, neurotransmitter plasticityl

In addition to small molecule neurotransmitters, such as norepinephrine and acetylcholine, sympathetic neurons often contain one or more neuropeptides. These include NPY, VIP, enkephalin, somatostatin, galanin, and calcitonin gene-related peptide (for review, see Elfvin et al., 1993). With appropriate stimuli, neuropeptides are released from nerve terminals and affect target cell function either directly by activating receptors within sympathetic target tissues or indirectly by modulating the release of small molecule transmitters and other neuropeptides from nerve terminals (IIokfelt, 1991). The complement of peptidergic phenotypes differs between ganglia, and adjacent neurons in a ganglion may possess distinct peptide phenotypes. For example, $3-5 \%$ of adult rat stellate neurons possess VIPIR (Landis and Fredieu, 1986), while only rare SCG neurons are VIP-IR (Hokfelt et al., 1977; Sasek and Zigmond, 1989). Further, a subpopulation of the VIP-IR neurons in the stellate ganglion, but not the SCG, contain CGRP (Landis and Fredieu, 1986; Lindh et al., 1987, 1989; Kummer and Heym, 1988). In contrast, NPY-IR is present in similar proportions of sympathetic neurons in different paravertebral ganglia (Jarvi et al., 1986; J. DeJonge, P. Henion and S. Landis, unpublished observations).

NPY and VIP are present in distinct subsets of sympathetic neurons and provide interesting contrasts with respect to function and colocalization with classical neurotransmitters. NPY is a vasoconstrictor (Lundberg et al., 1990; Owan, 1990) and inhibits secretion in a variety of tissues (Dunning et al., 1987; Walker et al., 1991). It also inhibits the release of norepinephrine, with which it is colocalized (Lundberg et al., 1990; Bleakman et al., 1992). On the other hand, VIP, a vasodilator (Owan, 1990) and a potent secretagogue (for reviews, see Ekstrom, 1990; Baraniuk and Kaliner, 1991), facilitates the release of both norepinephrine and acetylcholine (Nilsson et al., 1990; Pr $\angle y w a r a$ et al., 1991; Lefebvre et al., 1992; Takahasi et al., 1992; but see Bratveit and Helle, 1991). In adult ganglia, VIP is exclusively colocalized with acetylcholine (Lundberg et al., 1980, 1982; Lindh et al., 1989).

While the distribution and function of NPY and VIP in mature sympathetic neurons have been under investigation for some time, the mechanisms responsible for acquisition and regulation of their expression during development are incompletely understood. The developmental appearance of NPY-IR has been described in amphibians (Stofer and Horn, 1990, 1993) and that of NPY- and VIP-IR in birds (Hayashi et al., 1983; New and 
Mudge, 1986; Garcia-Arraras et al., 1987, 1992). These peptides are first detected in low concentrations and a few cells. With development, the concentration of NPY - and VIP-IR and the proportion of immunoreactive neurons increase. These observations suggest that expression of a particular neuropeptide is induced in neurons that will contain that neuropeptide when mature and that subsequent developmental regulation of peptide expression entails primarily increased expression. Since our understanding of sympathetic ganglion formation and maturation and preganglionic and postganglionic inncrvation in these species is incomplete, however, it is difficult to associate the acquisition of neuropeptide phenotypes with the developmental mechanisms responsible.

Sympathetic ganglia in rats provide an excellent system in which to examine the developmental mechanisms regulating neuropeptide expression because the development of ganglia and neurons, particularly the SCG, has been extensively studied in vivo and in vitro. Sympathetic precursor cells derived from neural crest first appear along the thoracic dorsal aorta at E10/ E11 and in the cervical region at E12 (Rubin, 1985a), where they begin to express TH-IR and catecholamines and proliferate to form ganglia (Cochard et al., 1978, 1979; Rothman et al., 1978; Teitelman et al., 1979; Rubin, 1985a). Soon after this, at $\mathrm{E} 13.5$, clonal analysis indicates that precursor cells are committed to either a neuronal or non-neuronal fate (Hall and Landis, 1991). Most sympathetic neuronal precursors undergo a terminal division between E12 and E16 (Hendry, 1977; Landis and Damboise, 1986) while glial precursors in the SCG are quiescent during this time and proliferate after E16 (Hall and Landis, 1991, 1992). The first preganglionic axons enter the SCG at $\mathrm{E} 13$ and with their arrival, postganglionic responses can be elicited (Rubin, 1985b,c). By E14, several hundred preganglionic fibers, one-sixth the adult complement, are present, and by birth, half the adult number are evident. Many sympathetic neurons first contact their target tissues during embryogenesis; the timing of this event appears variable and is partially dependent on the distance of the target from the ganglion. Sympathetic fibers are detected in the iris at E15 and are likely to reach closer targets before that (Rubin, 1985a). Distal targets, including pineal gland and sweat glands, are contacted after birth (Landis and Keefe, 1983; Li and Walsh, 1991). Since sympathetic neurons in the SCG at least are generated over 4-6 d, neurons at different developmental stages are present in embryonic ganglia. Although initial presynaptic and postsynaptic contacts are established before birth, major expansions in dendritic arborizations and preganglionic and postganglionic terminal plexuses occur after birth (Black and Mytilineou, 1976; Smolen and Raisman, 1980; Voyvodic, 1987). In addition to our knowledge of developmental events in sympathetic ganglia, differcntiation factors that influence neuropeptide expression in sympathetic neurons have been identified (Wong and Kessler, 1987; Adler et al., 1989; Ernsberger et al., 1989; Nawa and Patterson, 1990; Nawa and Sah, 1990; Nawa et al., 1991; Rao et al., 1992a-c; Fann and Patterson, 1993).

We examined the development of NPY and VIP expression in rat SCG and stellate ganglia and found that acquisition of mature peptide phenotypes is more complex than previously suspected. NPY and VIP were first detected early in development, in dividing neuroblasts as well as postmitotic neurons. At early stages, virtually all TH-IR cells in both ganglia contained NPY-IR, VIP-IR was evident in a subset of TH-IR cells in the stellate but not in SCG, and some stellate cells contained both peptides. With subsequent development, however, the proportion of cells with immunoreactivity for these peptides decreased and the phenotypes became segregated. Thus, restriction of neuropeptide expression plays an important role in shaping a neuron's neuropeptide repertoire.

\section{Materials and Methods}

Animals and dissection. Pregnant Sprague-Dawley rats were obtained from Zivic Miller (Zelienople, PA). At appropriate gestational ages (E1 1.5-E18.5), embryos were removed from the uterus following asphyxiation of the mother with carbon dioxide. Postnatal animals were killed by ether inhalation and staged according to the criterion of Christie (1962).

The degree to which the SCG and stellate ganglia were dissected free of surrounding tissue depended on the age of the animal and the technique with which the ganglion was to be analyzed. For immunocytochemical and in situ hybridization analyses, embryonic ganglia were fixed and sectioned with surrounding tissues. Young embryos (E11.5E13.5) were fixed and sectioned whole, while older embryos (E14.5E18.5) were partially dissected and pieces of tissue containing the ganglia were fixed and then sectioned. Sectioning embryonic ganglia with surrounding tissue prevented artifactual immunoreactivity at the edges of ganglia which, in small embryonic ganglia, could affect a large proportion of tissue. The presence of surrounding tissues also allowed determinations of background staining intensity and grain densities. Ganglia from postnatal animals were dissected completely. These ganglia were significantly bigger and edge artifacts affected only the connective tissue sheath and immediately adjacent cells; since immunoreactivity and grain densities were heterogeneously distributed, background levels were readily determined within ganglia. Ganglia used for RIA were completely dissected and placed in $2 \mathrm{~N}$ acetic acid on ice.

Immunocytochemistry. Tissue was fixed in 4\% paraformaldehyde in $0.1 \mathrm{~m}$ phosphate buffer. Embryonic tissue was immersed for $2.5 \mathrm{hr}$ at room temperature. Postnatal rat pups were perfused with fixative for $10 \mathrm{~min}$ and ganglia were dissected and immersed for $50 \mathrm{~min}$ at room temperature. Fixed tissue was equilibrated in $30 \%$ sucrose in phosphate buffer for cryoprotection. Frozen sections of $7 \mu \mathrm{m}$ (embryonic) or 10 $\mu \mathrm{m}$ (postnatal) were mounted on gelatin-coated slides.

Sections were labeled by rinsing in phosphate-buffered saline (PBS), preincubating in dilution buffer $(0.5 \mathrm{~m}$ sodium chloride, $0.01 \mathrm{M}$ phosphate buffer, $3 \%$ bovine serum albumin, $0.1 \%$ sodium azide, $0.3 \%$ Triton-X 100), and then incubating in dilution buffer containing $5 \%$ rat serum and primary antisera overnight. Antisera and the combinations in which they were used are listed in Tables 1 and 2. Sections were rinsed in PBS, incubated with the appropriate secondary antisera in dilution buffer with $5 \%$ rat serum, and rinsed. Peptide-IR was usually enhanced using secondary antisera conjugated to biotin followed by avidin conjugated to a fluorochrome in dilution buffer. Sections were mounted with glycerol:PBS (1:1) containing 1-2\% $N$-propyl gallate (Giloh and Sedat, 1982; Sigma, St. Louis, MO). In most cases, sections were either double or triple labeled using primary antisera raised in different species and species-appropriate secondary antibodies conjugated to distinct fluorochromes. Antiserum combinations are listed in Table 2. Several experiments were performed to control for nonspecific hinding or cross-reactivity of antisera. First, sections were incubated without the primary neuropeptide antisera. Second, NPY and VIP primary antisera were absorbed by incubating them with either NPY or VIP $(10 \mu \mathrm{g} / \mathrm{ml}$; Peninsula, Belmont, CA) for $2 \mathrm{hr}$ at room temperature. The mixture of antiserum and peptide was centrifuged to remove peptide-antibody complexes and the supernatant used as the primary antiserum. Following omission of the primary antiserum or absorption, only low background levels of fluorescence were evident. The developmental patterns of NPY - and VIP-IR were also confirmed using antisera generated in different species. Sections of ganglia from multiple ages were labeled in each experiment so that the immunofluorescence intensity could be compared.

The proportion of immunoreactive neurons and neuroblasts was determined from micrographs of sections labeled with antisera for $\mathrm{TH}$ and a neuropeptide. Cells were considered labeled if the intensity of immunofluorescence within them was greater than that of the surrounding tissue. The total number of neurons and neuroblasts was determined by counting the TH-IR cells. We did not detect TH-IR in E18.5 or postnatal day 0 (P0) VIP-IR neurons; therefore, at these ages, the total number of neurons was determined by adding the number of $\mathrm{TH}$ - and 


\begin{tabular}{llll}
\hline \multicolumn{1}{l}{ Table 1. Antisera used } & & \\
Antigen & Species of origin & Dilution & Supplier \\
\hline NPY & Guinea pig & $1: 250$ & P. D. Henion ${ }^{a}$ and M. S. Rao ${ }^{b}$ \\
NPY & Rabbit & $1: 500$ & Amersham \\
VIP & Guinea pig & $1: 300$ & P. D. Henion ${ }^{a}$ and M. S. Rao ${ }^{b}$ \\
VIP & Rabbit & $1: 500$ & P. Hogan \\
TH & Rabbit & $1: 200$ & Pel-freeze \\
TH & Mouse & $1: 1000$ & Boehringer Mannheim \\
TH & Mouse & $1: 500$ & Incstar \\
BrdU & Mouse & $1: 100$ & Boehringer Mannheim \\
Secondary antisera & & & \\
Antigen & Conjugate & Dilution & Supplier \\
\hline Guinea pig & Biotin & $1: 200$ & Amersham \\
Guinea pig & FITC & $1: 100$ & Jackson \\
Rabbit & Biotin & $1: 200$ & Amersham \\
Rabbit & FITC & $1: 400$ & Cappel \\
Mouse & Biotin & $1: 200$ & Amersham \\
Mouse & FITC & $1: 500$ & Antibodies Inc. \\
Avidin & Texas red & $1: 300$ & Amersham \\
Avidin & AMCA & $1: 300$ & Vector \\
\hline${ }^{a}$ University of Oregon, Eugene, OR. & & \\
${ }^{\circ}$ Cal Tech, Pasadena, CA. & & \\
${ }^{c}$ Harvard University, Boston, MA. & &
\end{tabular}

VIP-IR neurons. To avoid counting the same cells twice, only cell profiles with a nucleus were counted and sections located at least 35 (E14.5), 70 (E16.5-E18.5), or $100(\mathrm{P} 0) \mu \mathrm{m}$ apart were analyzed. Data were collected and pooled from at least three sections through different regions of ganglia, and the percentage of total neurons and neuroblasts immunoreactive for either NPY or VIP was calculated.

5-Bromo-2'-deoxyuridine (BrdU) incorporation into dividing cells. Dividing cells were labeled in vivo using a modified version of the procedure described by Miller and Nowakowski (1988). 5-Bromo-2'-deoxyuridine (BrdU; Sigma) was injected intraperitoneally into pregnant SpragueDawley rats on the appropriate gestational day $(0.1 \mu \mathrm{g} / \mathrm{gm})$. One hour later, a second injection was administered and the animals were killed $3 \mathrm{hr}$ after the second injection. Since BrdU is cleared rapidly, multiple injections increased the time it was available for incorporation, resulting in more intense labeling of a larger proportion of the dividing cells. Sections $(5 \mu \mathrm{m})$ of sympathetic ganglia from treated embryos were labeled with NPY or VIP antiserum followed by a fluorochrome-conjugated secondary antiserum. In some cases, the sections were also labeled with anti-TH antiserum. The antibodies were fixed on the section by incubating slides in $4 \%$ paraformaldehyde for $20 \mathrm{~min}$ followed by a 40 min incubation in $2 \mathrm{~N} \mathrm{HCl}$ to denature DNA. The sections were labeled overnight with a mouse monoclonal anti-BrdU antibody diluted in PBS with $0.5 \%$ Tween-20 and 5\% rat serum, rinsed with PBS and Tween20 , and labeled with a secondary antiserum conjugated to a third fluorochrome.

Radioimmunoassay. Ganglia were homogenized in $2 N$ acetic acid by sonication and boiled for $5 \mathrm{~min}$. Samples were centrifuged for $2 \mathrm{~min}$ and the supernatants were aliquoted, lyophilized, and stored at $-70^{\circ} \mathrm{C}$. Protein assays were performed on some aliquots using the Micro BCA kit (Pierce, Rockford, IL). To normalize data obtained at different times or using different assays, peptide levels were expressed as the percentage relative to E14.5 stellate (VIP) or E16.5 (NPY) samples assayed simultaneously.

VIP-IR was assayed either using a commercially available RIA kit (Incstar, Stillwater, MN) or the method described by Hyatt-Sachs (Hyatt-Sachs et al., 1993). When the kit was used, the protocol supplied with the kit was followed. A brief description of the other protocol follows. Samples were reconstituted in assay buffer $[0.1 \mathrm{M}$ phosphate buffer, $0.05 \mathrm{M} \mathrm{NaCl}, 0.01 \mathrm{M}$ EDTA, $0.1 \%$ bovine serum albumin (Sigma), $0.1 \%$ Triton-X, and $0.19 \mathrm{TIU} / \mathrm{ml}$ aprotinin (Sigma)]. Either standard concentrations of VIP (Bachem, Philadelphia, PA) or the unknown samples were then incubated overnight with rabbit anti-VIP (Peninsula). On the following day ${ }^{125}$ I-VIP (DuPont-New England Nuclear, Boston, MA) was added and the mixture incubated overnight. On the third day, goat anti-rabbit IgG and normal rabbit serum (Peninsula) were added, the samples incubated for $2 \mathrm{hr}$, and then centrifuged at $1700 \times g$ for 20 min. Pellets were counted in a gamma counter.

NPY-IR was measured using RIA kits from Peninsula. For some samples, NPY-IR was measured with an RIA kit utilizing an antiserum directed against porcine NPY, which displays $64 \%$ cross-reactivity with rat NPY. Therefore, rat NPY, and not porcine NPY, was used for a standard curve. NPY-IR in other samples was measured with a kit

Table 2. Combinations of antisera used

$\begin{array}{ll}\text { TH/NPY } & \text { Rabbit anti-TH/guinea pig anti-NPY } \\ & \text { Mouse anti-TH/rabbit anti-NPY } \\ \text { TH/VIP } & \text { Rabbit anti-TH/guinea pig anti-VIP } \\ & \text { Mouse anti-TH/rabbit anti-VIP } \\ \text { NPY/VIP } & \text { Rabbit anti-NPY/guinea pig anti-VIP } \\ & \text { Guinea pig anti-NPY/rabbit anti-VIP } \\ \text { NPY/BrdU } & \text { Guinea pig anti-NPY/mouse anti-BrdU } \\ \text { VIP/BrdU } & \text { Guinea pig anti-VIP/mouse anti-BrdU } \\ \text { TH/NPY/BrdU } & \text { Rabbit anti-TH/guined pig anti-NPY/mouse anti-BrdU } \\ \text { TH/VIP/BrdU } & \text { Rabbit anti-TH/guinea pig anti-VIP/mouse anti-BrdU }\end{array}$



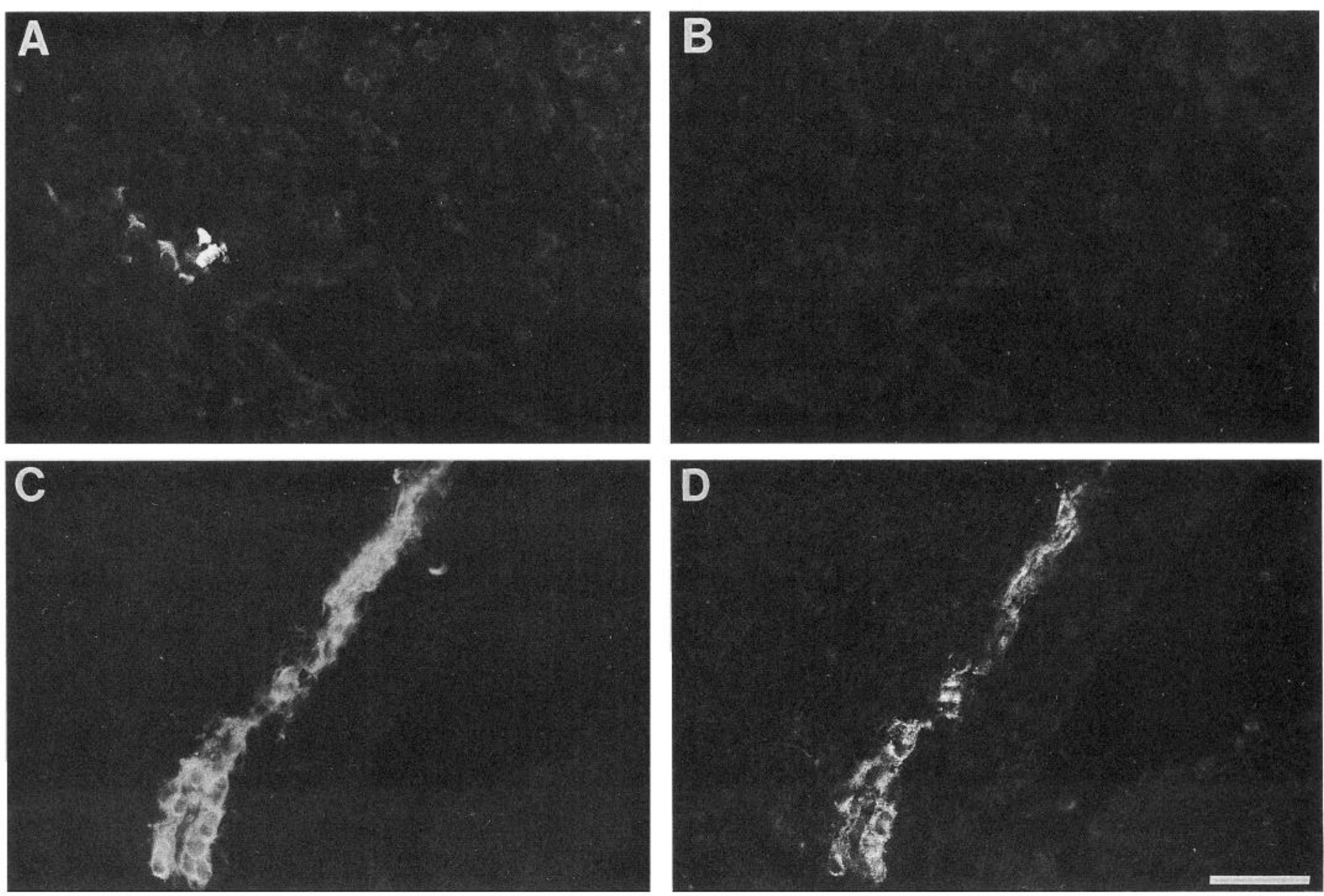

Figure 1. The appearance of NPY-IR in rat sympathetic precursors and ganglia. Rat embryo sections were labeled for TH and NPY. At E11.5 TH-IR sympathetic precursors in the thoracic region $(A)$ do not possess NPY-IR $(B)$; by E12.5, however, virtually all TH-IR cells in both thoracic and cervical regions $(C)$ are uniformly NPY-IR $(D)$. Scale bar, $50 \mu \mathrm{m}$.

utilizing an antibody directed against rat NPY (Peninsula). In this case, the standards provided with the kit were used.

In situ hybridization. Tissue used for in situ hybridization was frozen in Tissue Tek on dry ice immediately. Embryonic and postnatal tissues were sectioned at 7 or $10 \mu \mathrm{m}$, respectively, and sections were mounted on gelatin-coated slides so that the tissue thawed only momentarily. Sections were stored at $-70^{\circ} \mathrm{C}$.

Oligonucleotide probes complementary to NPY and VIP mRNA were used to localize peptide mRNA. The probe complementary to NPY mRNA was 45 nucleotides in length (bases 106-151; Larhammar et al., 1987). This region is not conserved in other members of the pancreatic polypeptide gene family. The probe complementary to VIP was 47 nucleotides in length (bases 403-449; Nishizawa et al., 1985). Both were made using solid-phase synthesis on an Applied Biosystems DNA synthesizer, gel purified, and stored at $4^{\circ} \mathrm{C}$. Prior to use they were labeled on the $3^{\prime}$ end using terminal deoxynucleotidyl transferase (Bethesda Research Labs, Gaithersburg, MD) and ${ }^{35}$ S-deoxyadenosine $5^{\prime}-(\alpha$-thio) triphosphate (New England Nuclear; Siegel, 1989).

In situ hybridization was performed as described by Siegel (1989). Briefly, slides were warmed to room temperature, fixed in $4 \%$ formaldehyde, rinsed in PBS, and incubated in $0.25 \%$ acetic anhydride. The slides were quickly rinsed in $2 \times \operatorname{SSC}(0.3 \mathrm{~m}$ sodium chloride, $0.03 \mathrm{~m}$ sodium citrate, $\mathrm{pH}$ 7; Sigma), dehydrated with ethanol, and air dried. Once dry, the tissue was incubated in hybridization buffer $(4 \times \mathrm{SSC}$, $50 \%$ formamide; Fisher, Fair Lawn, NJ), $500 \mu \mathrm{l} / \mathrm{ml}$ sheared singlestranded DNA (Boehringer Mannheim, Indianapolis, IN), $25 \mu \mathrm{l} / \mathrm{ml}$ yeast tRNA (Collaborative Research, Bedford, MA), $1 \times$ Denhardt's solution, and $10 \%$ dextran sulfate (Sigma) without the probe. Slides were incubated overnight in hybridization buffer containing $7 \times 10^{5} \mathrm{cpm}$ of ${ }^{35} \mathrm{~S}$ labeled probe. The slides were then washed in $2 \times \mathrm{SSC} / 50 \%$ formamide at $40^{\circ} \mathrm{C}$ and then in $1 \times \mathrm{SSC}$ at room temperature, dipped in water, and allowed to dry. Slides were dipped in Kodak NTB-3 emulsion (Rochester, NY) diluted $1: 1$, and placed in desiccated chambers at $4^{\circ} \mathrm{C}$ for 6 weeks. They were developed using D-19 developer (Kodak), fixed, and counterstained with cresyl violet.

In one experiment, in situ hybridization was performed on embryonic tissue fixed prior to sectioning. Embryos were removed, and ganglia were partially dissected and immersed for $2.5 \mathrm{hr}$ in $5 \%$ sucrose and $4 \%$ paraformaldehyde in $0.1 \mathrm{M}$ phosphate buffer at room temperature, followed by an overnight incubation in $30 \%$ sucrose and $4 \%$ paraformaldehyde. Sections were cut the next day, stored at $-70^{\circ} \mathrm{C}$, and processed as described except that fixation was omitted and sections were incu-

\footnotetext{
Figure 2. The distribution of NPY-IR in sympathetic ganglia during embryonic development. Rat embryo sections were labeled for TH and NPY. At E14.5 cells in the SCG were TH-IR $(A)$ and NPY-IR $(B)$, while immunoreactivity for neither antigen was detected in adjacent nodose ganglia $(n g)$. At E16.5 the intensity of immunoreactivity was no longer uniform; some cells were more brightly immunoreactive than at earlier ages, while other cells were less $(C)$. At all ages the distribution of NPY-IR within SCG and stellate ganglia was similar, as demonstrated in E16.5 SCG $(C)$ and stellate ganglia $(D)$. At P0 many SCG TH-IR neurons $(E)$ were not NPY-IR $(F)$. In $F$, arrows indicate neurons classified as NPY-IR, while arrowheads indicate neurons classified as not immunoreactive. Scale bar, $50 \mu \mathrm{m}$.
} 

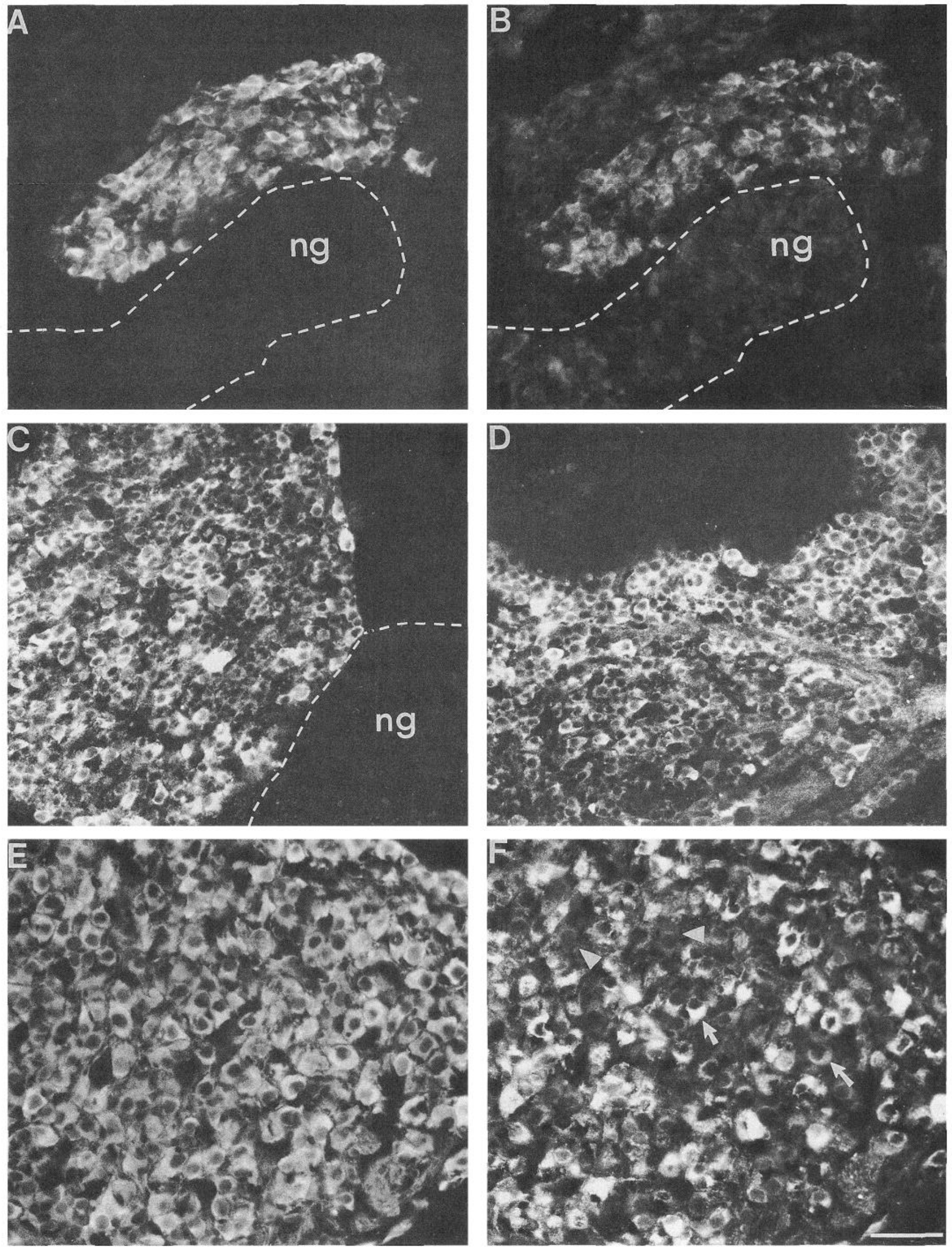


\section{A. Superior Cervical Ganglion}

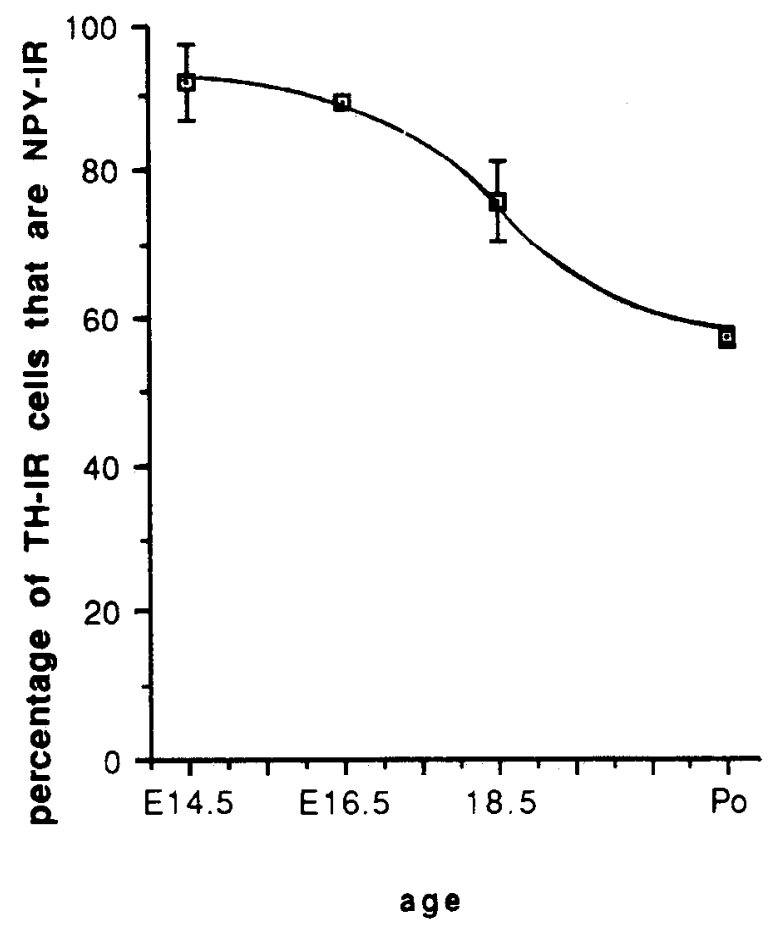

\section{B. Stellate Ganglion}

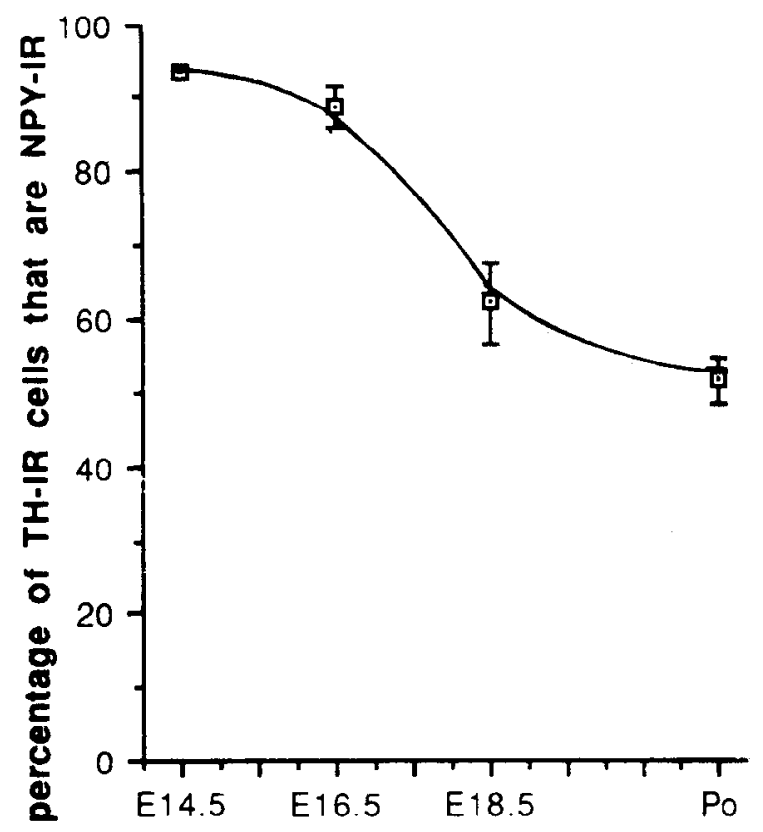

age

Figure 3. Proportion of NPY-IR neurons in embryonic and neonatal sympathetic ganglia during development. The percentage of TH-IR cells that were NPY-IR was determined by counting cell profiles from micrographs of double-labeled sections. To avoid counting cells twice, only bated for $6 \mathrm{~min}$ in $0.1 \mathrm{~m}$ glycine and rinsed with PBS prior to incubation in acetic anhydride. While this resulted in improved structure, specific grain densities were reduced.

As neuron size increased, the distribution of grains within ganglia could be examined in detail. The grain densities over neurons in sections hybridized with the probe complementary to NPY mRNA were measured using the Cue 4 image analysis system (Olympus, Overland Park, KS). For this analysis, only sections hybridized, dipped, and developed at the same time were analyzed. Specific grain densities over sections of P0 and adult SCG were calculated by subtracting the background, or mean grain density from an area of the ganglion without neurons plus $1 \mathrm{SD}$, from the grain densities over neurons. Three SCG were assayed by measuring grain densities over all neurons in a section and plotting frequency distributions for these densities. Gaussian and exponential curves were fitted to the data using the PASSAGE II program that weighted each value using its standard deviation and gave a $\chi^{2}$ value representing the closeness of the fit. A $\chi^{2}$ value was used to test the validity of the fit (Bress et al., 1989). The percentage of postnatal stellate neurons with VIP mRNA was determined by counting the total number of cresyl violet-stained neurons and the number of neurons with grain densities above background levels.

\section{Results}

Neuropeptide $Y$

NPY-IR was present in most TH-IR cells in the thoracic and cervical regions soon after TH-IR cells began to coalesce to form ganglia; the proportion of TH-IR cells with NPY-IR, however, decreased during subsequent development. At E12.5, $1 \mathrm{~d}$ after TH-IR sympathetic precursors are present in the thoracic region (Cochard et al., 1978; Teitelman et al., 1978, 1979) and the same day they reach the cervical region (Rubin, 1985a), NPYIR was first detected in sympathetic ganglia (Fig. 1). NPY-IR was never seen in adjacent sensory ganglia (Fig. 2). When it first appeared, NPY-IR was present in almost all TH-IR cells and the peptide immunofluorescence was faint throughout the cytoplasm (Fig. 1). During the next $3 \mathrm{~d}$, the proportion of TH-IR cells with peptide-IR remained relatively constant while the intensity of peptide immunofluorescence increased. At E16.5, the immunofluorescence intensity of NPY-IR began to appear heterogeneous; some cells were more brightly immunoreactive than others (Fig. 2). As development proceeded, the proportion of cells with detectable NPY-IR decreased significantly (ANOVA, $p<0.0001$ ) from approximately $90 \%$ in both the SCG and the stellate ganglion at E16.5 to $76 \%$ at in the SCG and $62 \%$ in the stellate ganglion at E18. By $\mathrm{P} 0$, the proportion of neurons with NPY-IR was $57 \%$ in the SCG and $52 \%$ in the stellate ganglion (Fig. 3), proportions similar to those in the adult (Jarvi et al., 1986; DeJonge, Henion, and Landis, unpublished observations). While the percentage of TH-IR cells expressing NPYIR was decreased in the adult relative to E14.5, the intensity of NPY-IR in immunoreactive neurons continued to increase both prenatally and postnatally (Fig. 2).

Since NPY was present in the majority of TH-IR cells before most neurons in sympathetic ganglia have been generated, it seemed likely that NPY was cxpressed not only by postmitotic

profiles containing a nucleus were counted and all sections counted were located at least 35 (E14.5), 70 (E16.5-E18.5) or 100 (P0) $\mu \mathrm{m}$ apart. At E14.5 and E16.5, almost all TH-IR cells were also NPY-IR. After E16.5, however, the proportion of TH-IR cells possessing NPY-IR declined until P0 when the adult pattern was established. Changes in the percentage of NPY-IR neurons after E16.5 were statistically significant (ANOVA, $p<0.01$ ). The percentage of NPY-IR cells was determined in at least three sections each from three different ganglia for each time point. The number of cells counted from each animal ranged from 308 to 4595 . Error bars represent standard deviation. 

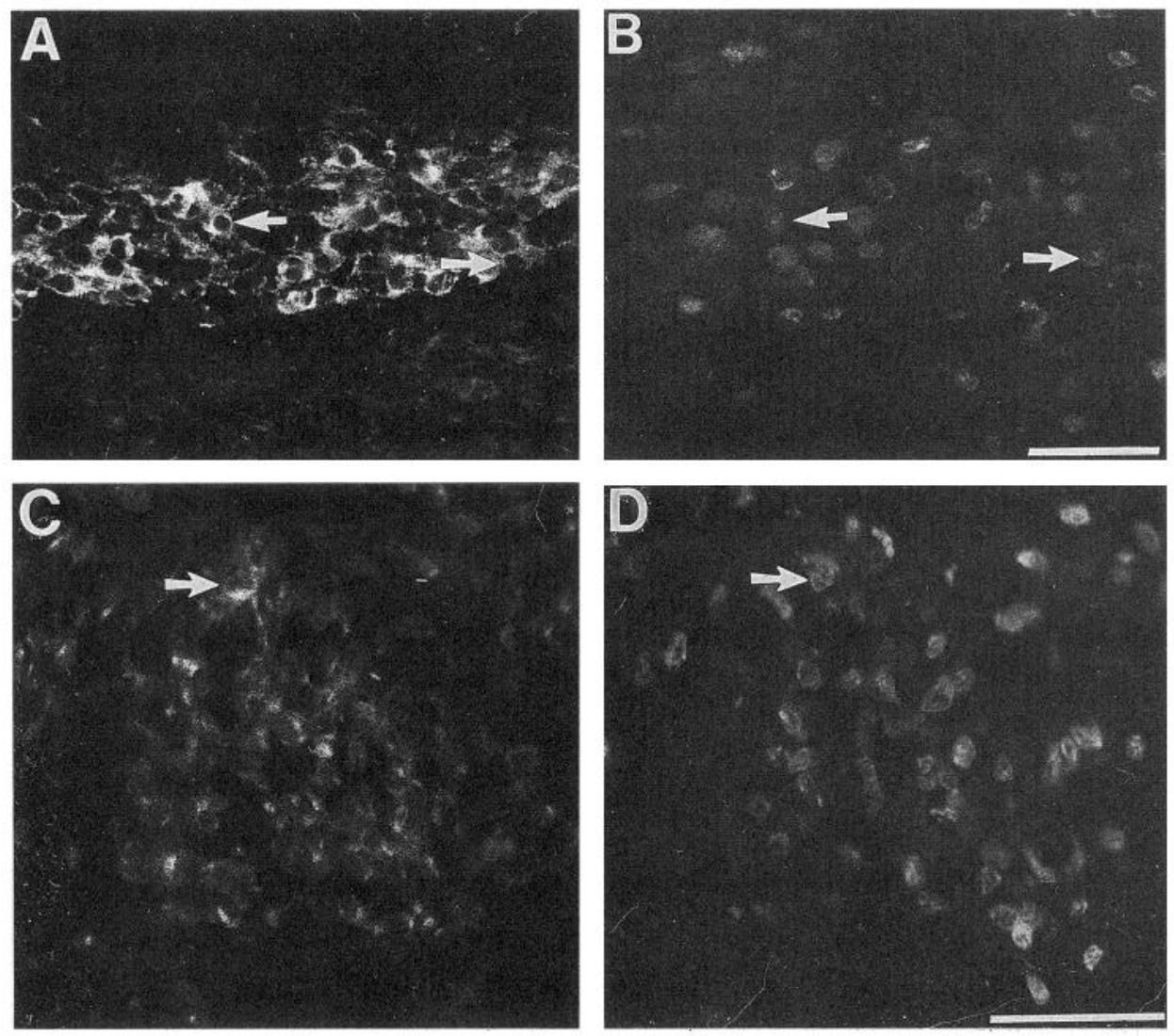

Figure 4. NPY-IR and VIP-IR are present in sympathetic neuroblasts. E14.5 rat embryos were exposed to the thymidine analog BrdU and killed $4 \mathrm{hr}$ after the first injection. Sections were double labeled for NPY or VIP and BrdU. Several NPY-IR cells in stellate ganglia $(A)$ also possessed BrdU-IR nuclei $(B$, arrows), indicating that NPY is present in dividing cells. The fluorescence intensity of BrdU-IR nuclei in the ganglion was less than that of nuclei in surrounding tissues. VIP-IR cells in stellate ganglia $(C)$ also possessed $\mathrm{BrdU}$ IR nuclei ( $D$, arrows). Some of the dividing cells possessed faint VIP-IR, while others were more brightly labeled. Scale bars, $50 \mu \mathrm{m}$. neurons but also by neuroblasts. To examine this question directly, E14.5 embryos were exposed in utero to BrdU, a thymidine analog incorporated into dividing cells, and then ganglia were processed for immunocytochemistry $4 \mathrm{hr}$ later. These experiments were done at E14.5 because NPY-IR was brighter than at earlier ages and many sympathetic neuron but few glial precursors are dividing (Hendry, 1977; Landis and Damboise, 1986; Hall and Landis, 1992). Sections of ganglia from embryos exposed to BrdU were double labeled with antisera against NPY and BrdU. Numerous BrdU-IR nuclei were present in both SCG and stellate ganglion and many NPY-IR cells within the SCG and stellate ganglia possessed BrdU-IR nuclei (Fig. 4). In some experiments, sections were also labeled with an antiserum recognizing TH. The presence of all three markers in individual cells confirmed that sympathetic neuroblasts expressed NPY prior to their final division.

Immunocytochemical analysis revealed alterations in NPYIR during embryonic development, suggesting that the concentration of NPY within the ganglia was changing. To address this possibility, NPY content was analyzed by RIA (Fig. 5). NPYIR was present in similar concentrations in the SCG and stellate ganglion at E14.5, the earliest age at which it was feasible to collect cleanly dissected ganglia. By E16.5, NPY-IR concentrations in each ganglion had increased (ANOVA, $p<0.05$ ), but with further development they decreased (ANOVA, $p<0.05$; Fig. 5) so that by birth the concentrations of NPY were approximately $40 \%$ of those detected at E16.5. While in general, changes in NPY-IR assayed by RIA parallel those assayed by immunochemistry, the NPY concentration measured by RIA decreased more than the number of NPY-IR reactive cells. This may reflect the fact that glial cells begin to divide late in em- bryogenesis and neurons would therefore contribute a smaller proportion of the total ganglionic protein (Hall and Landis, 1991, 1992).

SCG and stellate, but not sensory, ganglia specifically hybridized a probe complementary to NPY mRNA during embryonic development. At E14.5, when sympathetic ganglia could be reliably identified by anatomical position, grains indicating specific hybridization were present over the entire SCG and stellate ganglia. With further development, the grain density increased (Fig. 6). Because the embryonic cells were small, grains could not be localized over individual cells until $\mathrm{P} 0$, at which age grains were concentrated over neurons but not glial cells (Fig. 7).

While at birth, most sympathetic neurons possessed grain densities above background and the density of grains over most neurons was similar, in adult ganglia, significant differences in grain densities were evident between neurons. To examine grain distributions in more detail, we measured the specific grain densities of all neurons in sections of P0 and adult SCG and fitted Gaussian curves to the resulting frequency distributions of those densities (Fig. 7). While the P0 distribution was fit with one Gaussian curve, the adult distribution was not. It was, however, fit with two Gaussian curves, while neither data set could be fit with exponential curves. One of the mean values for the two populations of grain densities in the adult is lower than the mean value for $\mathrm{P} 0$ neurons, while the other is higher. Further, the higher density population contains approximately $60 \%$ of SCG neurons, while the lower density population constitutes about $40 \%$ of these neurons. These percentages are the same as the proportion of neurons that do and do not possess NPY-IR in adult animals. Since differences in NPY-IR in individual 
A. Superior Cervlcal Gangllon

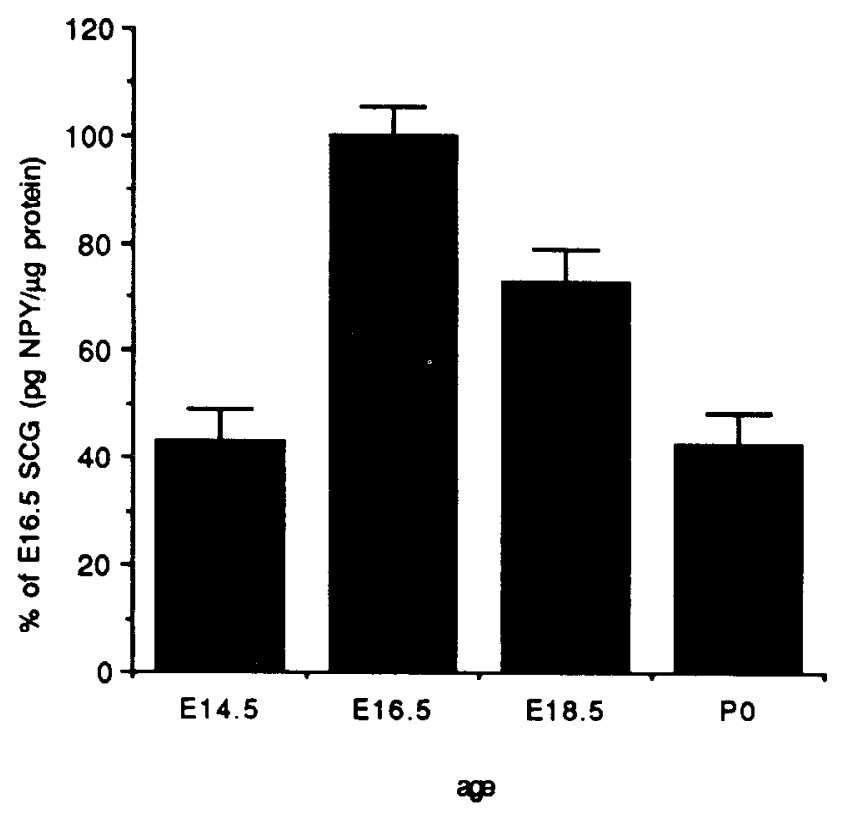

B. Stellate Ganglion

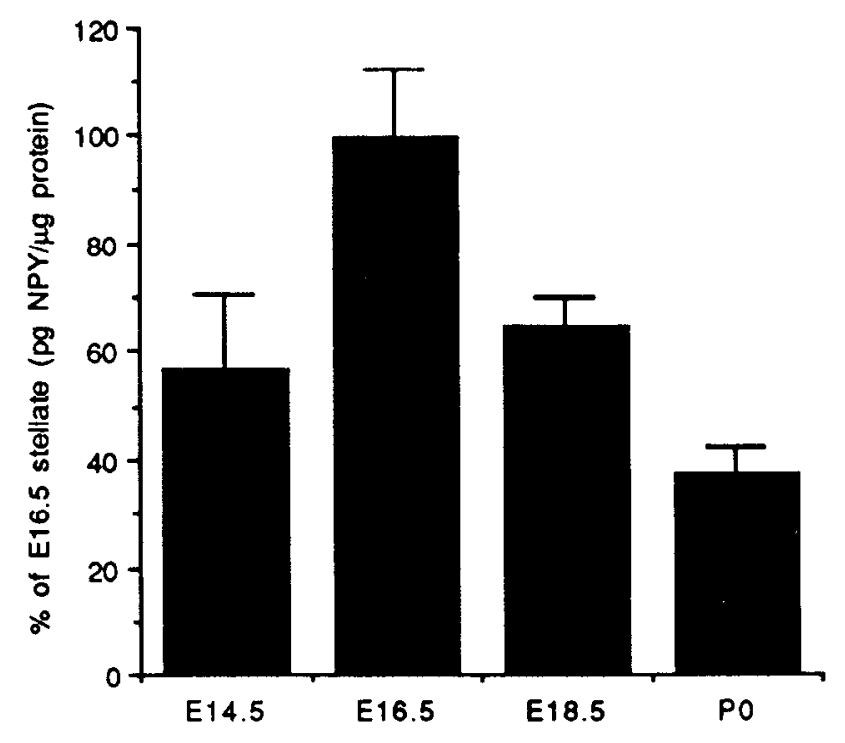

29

Figure 5. Changes in the concentration of NPY-IR during development. NPY-IR was measured in extracts of SCG $(A)$ and stellate ganglia $(B)$ by RIA. Because at these ages sympathetic ganglia are small, each extract contained ganglia from several animals. Data collected at different times or with different kits were normalized by expressing them as a percentage of E16.5 values determined simultaneously. All values are statistically different from the earlier age; in the SCG E14.5 is not different from $P 0$, and in the stellate ganglion E14.5 is not different from either F.18.5 or P0 (ANOVA; $p<0.05$ ). Frror hars represent SEM in one direction only. The numbers of different extracts assayed for each age are as follows: $\mathrm{E} 14.5 \mathrm{SCG}=4, \mathrm{E} 16.5 \mathrm{SCG}=5, \mathrm{E} 18.5 \mathrm{SCG}=9$, neurons were evident at $\mathrm{P} 0$ while the segregation into two populations based on mRNA content does not occur until later, differences in NPY-IR between individual neurons emerge before differences in NPY mRNA.

\section{Vasoactive intestinal peptide (VIP)}

VIP was differentially expressed in the SCG and stellate ganglion throughout development. Although cells and fibers containing immunocytochemically detectable VIP-IR were never observed in embryonic or neonatal SCG, many VIP-IR cells and fibers were present in stellate ganglia after E14.5 (Fig. 8). Furthermore, while VIP mRNA was not detected in embryonic or neonatal SCG using in situ hybridization histochemistry, specific grains were located over stellate ganglia. While we could not detect VIP or its mRNA in individual cells in SCG, we were able to measure VIP-IR in SCG extracts. Its concentration was always severalfold lower than that in extracts of stellate ganglia from the same animals (Fig. 9).

The differences in VIP-IR in SCG and stellate ganglia became apparent at E14.5. At E13.5, no VIP-IR cells were detectable in either ganglion, but by E14.5, approximately one-third of TH-IR cells in the stellate ganglia, but not the SCG, possessed VIP-IR (Fig. 8). VIP-IR was not seen in sensory neurons in adjacent dorsal root or nodose ganglia. The appearance of VIPIR at E14.5 in stellate ganglia but not SCG was observed with two independently generated antisera. At L14.5 the intensity of immunofluorescence varied considerably between cells and many immunoreactive cells were faintly labeled. As a consequence, it was difficult to determine the percentage of immunoreactive cells at E14.5 with the same accuracy as at older ages, and thus the percentage at this age is an estimate. After E14.5, the intensity of immunoreactivity exhibited by individual cells increased, allowing VIP-IR cells to be counted and percentages of immunoreactive cells calculated (Fig. 10). Following the initial appearance of VIP-IR in approximately one-third of THIR cells, the proportion of VIP-IR cells declined rapidly (ANOVA, $p=0.01$ for data from E16.5 to P0), and by $\mathrm{P} 0$, only $3.5 \%$ of the neurons within the stellate ganglion possessed VIP-IR. This percentage is similar to that in ganglia from adult animals (Landis and Fredieu, 1986).

The appearance of VIP-IR, like that of NPY-IR, overlaps with the period of neurogenesis. To detcrminc if sympathoblasts contained VIP-IR, dividing cells were labeled with BrdU at E14.5. Some, but not all, cells with BrdU-IR also possessed VIP-IR, indicating that a subset of dividing cells within the stellate ganglion were VIP-IR (Fig. 4). These cells were also THIR and are therefore sympathetic neuron precursors. Since the intensity of VIP-IR varied between individual BrdU-IR sympathetic precursors, the differences observed in immunofluorescence intensity did not appear to be correlated with neuronal birthdates.

In mature animals, VIP is found in cholinergic neurons that lack immunoreactivity for TH and NPY (Hokfelt et al., 1977; Lundberg et al., 1979, 1982; Lindh et al., 1989). When VIP-IR initially appeared in embryonic stellate ganglia at E14.5 and E16.5, however, it was colocalized with TH-IR. Since many cells contained NPY-IR, it seemed likely that VIP-IR was also

$\mathrm{P0}$ SCG $=5$, E14.5 stellate $=4$, E16.5 stellate $=8$, E18.5 stellate $=9$, P0 stellate $=5$. 

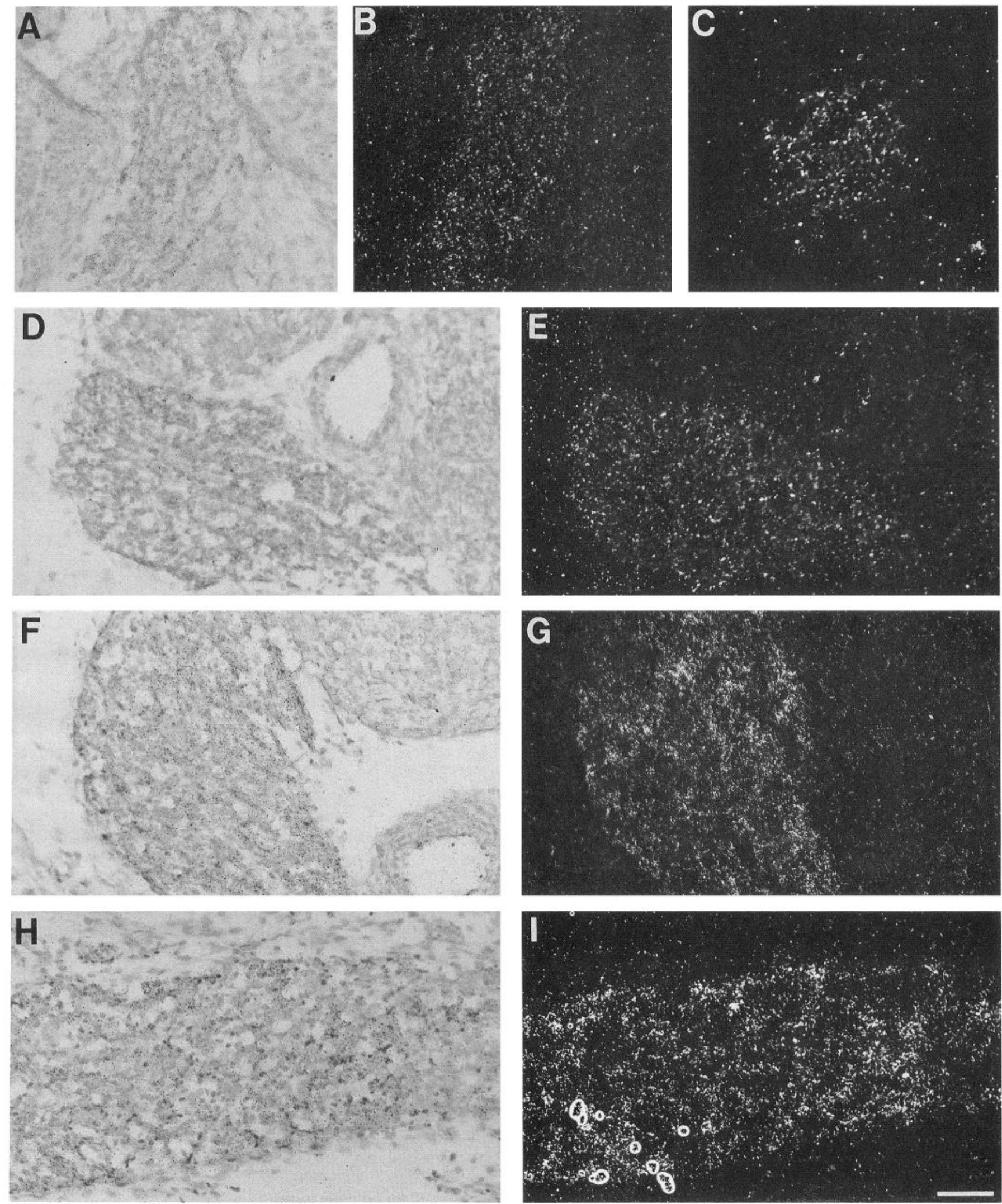

Figure 6. Development of NPY mRNA in embryonic sympathetic ganglia. Sections of rat symbathetic ganglia, which were fixed prior to sectioning, were examined with bright-field $(A, D, F$, and $H)$ or dark-field $(B, E, G$, and $I)$ microscopy 1 silowing hybridization with a probe complementary to NPY mRNA. The micrographs are of sections from fixed tissue, hybridized, dipped in emulsion, and developed at the same time. At E14.5 $(A$ and $B$ ) above-background levels of grains were present over the SCG. Although fixation of tissue prior to sectioning resulted in better morphological preservation of the tissue, more grains were present when the tissue was frozen immediately following dissection and fixed after sectioning, as shown in a section from E14.5 SCG $(C)$. By E16.5 (D and $E$ ), the density of grains over SCG had increased and this continued to be evident in E18.5 SCG $(F$ and $G)$. At all ages grain distributions were similar in SCG and stellate ganglia, as shown in E18.5 stellate ganglia $(H$ and $I)$. At no stage were above background grain densities located over adjacent nodose ganglia. Scale bar, $50 \mu \mathrm{m}$. 

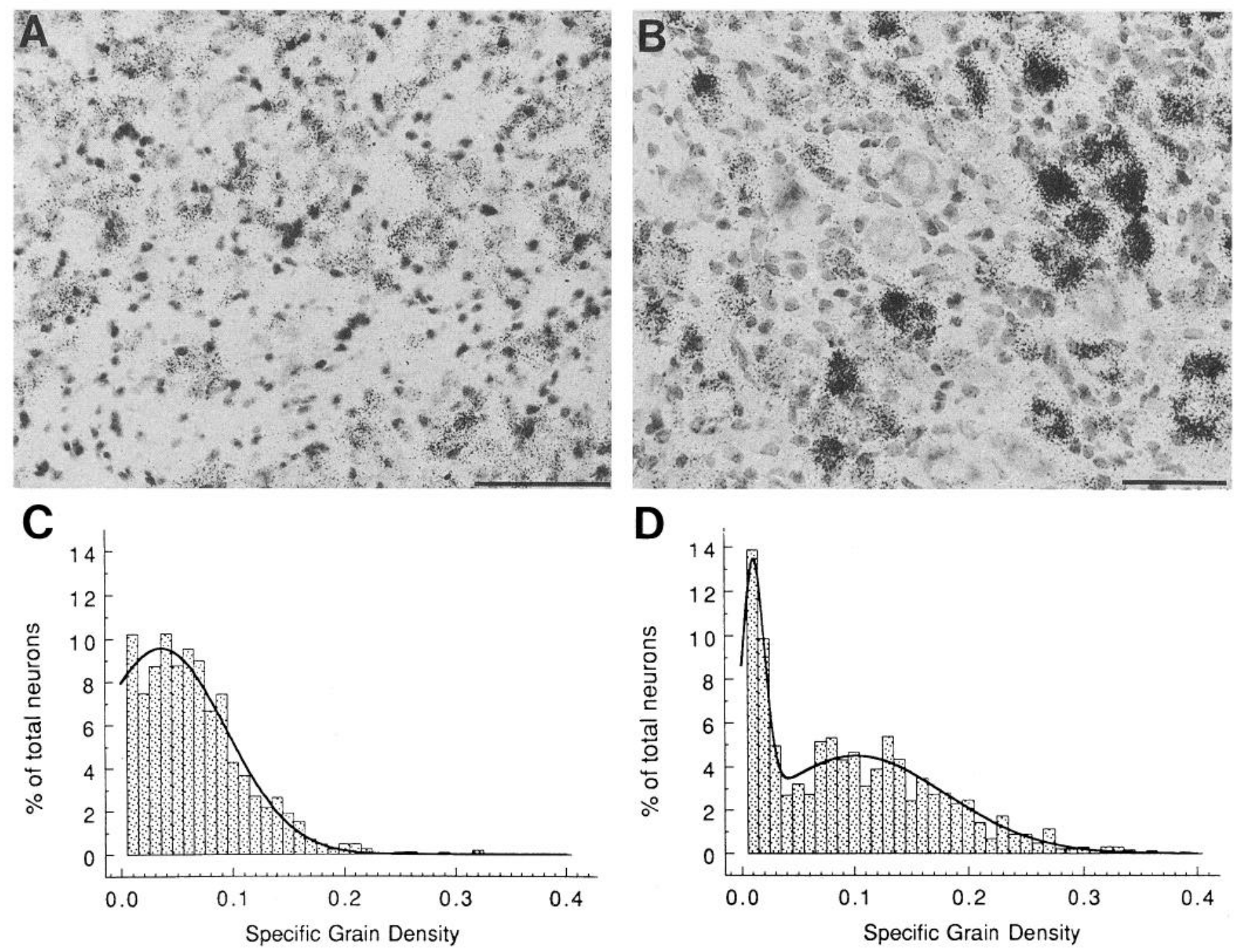

Figure 7. Postnatal modification of NPY mRNA distribution. Sections of rat SCG were examined with bright-field microscopy following hybridization with a probe complementary to NPY mRNA. At P0 $(A)$ grains were located over neuronal cell bodies. While the grain density varied, only one population of neurons appeared to be present. In sections from adult SCG $(B)$, many neurons had higher grain densities over them than at P0; however, many neurons had fewer grains than at P0. The average grain densities over SCG sections that were hybridized, dipped in emulsion, and developed at the same time were measured, frequency distributions of grain density/area over SCG neurons plotted, and Gaussian curves fitted to the data by least squares fitting. Although standard deviations are not shown, they were used to fit the data and are reflected in the $\chi^{2}$ value for the fit. Data from P0 animals were fit with one Gaussian curve $(C)$ while data from adult animals were fit with two Gaussian curves. The validity of these fits was tested using the "goodness-of-fit" test. Neither curve could be fit with an exponential curve. Three ganglia were examined at each age; this included a total of 859 cells for P0 data and 1036 cells for adult data. Scale bar, $50 \mu \mathrm{m}$.

colocalized with NPY-IR. We examined the possible colocalization of NPY and VIP at E16.5 when peptide-IR was relatively robust and found that almost every VIP-IR cell also possessed NPY-IR (Fig. 11). In many cases, VIP-IR was found in less intensely NPY-IR cells; these may represent cells in which NPY content was decreasing as VIP content was increasing. There were also examples of cells that were brightly immunoreactive for both peptides. At E18.5 and P0, VIP-IR was only detected in cells that lacked TH-IR. Since NPY-IR was restricted to THIR neurons at all ages examined, it seems likely that VIP-IR was not colocalized with NPY-IR at either E18.5 or P0.

Changes in the concentrations of VIP-IR in ganglion extracts were measured using RIA. The highest concentration of VIPIR was found in E14.5 stellate ganglia. With subsequent development, VIP-IR concentration decreased rapidly (ANOVA, $p 0.01$ ), leveling off at P0 at approximately $5 \%$ of the E14.5 value (Fig. 9). Extracts of SCG also contained VIP-IR, and although the concentration of VIP in the SCG was severalfold less than in extracts of stellate ganglia of the same age, it followed a similar developmental pattern. The concentration of VIP-IR in SCG was highest at E14.5 and decreased to approximately $5 \%$ of that value by P0. Interestingly, extracts of E14.5 SCG contained more VIP-IR per microgram of protein than extracts of P0 stellate ganglia, despite the fact that immunocytochemical methods detected VIP-IR neurons in the stellate ganglion, but not the SCG.

In situ hybridization with an oligonucleotide probe complementary to VIP mRNA indicated that VIP-IR was correlated with VIP gene expression within the ganglia; silver grains were located specifically over the stellate ganglion but not SCG, dorsal root ganglia, or nodose ganglia in E14.5 and older rats. Initially, silver grains were distributed throughout the ganglion and were 

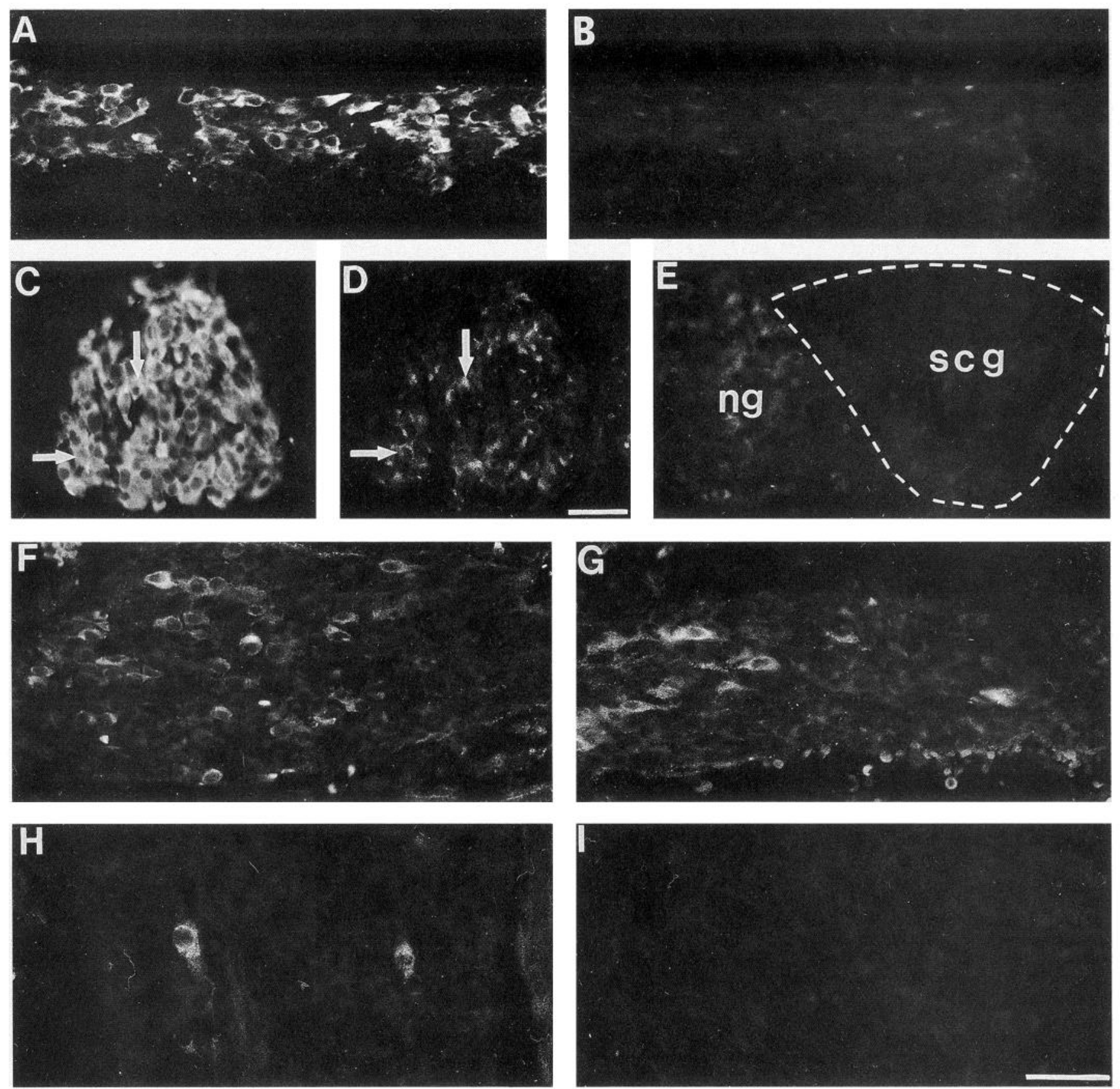

Figure 8. Developmental distribution of VIP-IR in embryonic sympathetic ganglia. Rat embryo sections were labeled for VIP. VIP-IR appears during the early development of the stellate ganglion. At E13.5, TH-IR cells $(A)$ are not VIP-IR $(B)$. At E14.5, approximately one-third of TH-IR stellate cells $(C)$ are VIP-IR $(D)$, while no VIP-IR cells are present in the SCG $(s c g, E)$. Although some cells in the nodose ganglion $(n g, E)$ appeared to be faintly VIP-IR, equivalent immunofluorescence was observed when primary antisera were omitted. The intensity of VIP-IR in stellate cells at E14.5 is variable and faint in most cells. By E16.5, a smaller proportion of stellate cells are VIP-IR; however, the intensity of immunoreactivity within individual cells is increased $(F)$. These changes are even more pronounced by E18.5 $(G)$ and P0 $(H)$. No VIP-IR cells are seen in sections of embryonic or neonatal SCG $(I) . A / B$ and $C / D$ are photomicrographs of the same field double labeled for TH and VIP. Scale bars: $A-D, 17 \mu$ m; $E-I, 50 \mu \mathrm{m}$.

not clustered over different regions. By E16.5, grains were unevenly distributed over stellate ganglia and by $\mathrm{P} 0$, they were clearly localized over a subset of individual neurons (Fig. 12). During the first 2 postnatal weeks the percentage of neurons with grain densities above background levels decreased (Fig. 13; ANOVA, $p<0.05$ ) followed by a slight increase at P21 to adult levels.

\section{Discussion}

The patterns of NPY and VIP expression in sympathetic ganglia during embryonic development, while distinct, share several features. Although NPY-IR appeared $2 \mathrm{~d}$ before VIP-IR, both peptides were present early in embryonic development. A significantly greater percentage of embryonic cells than adult neu- 
SCG \& Stellate Ganglion

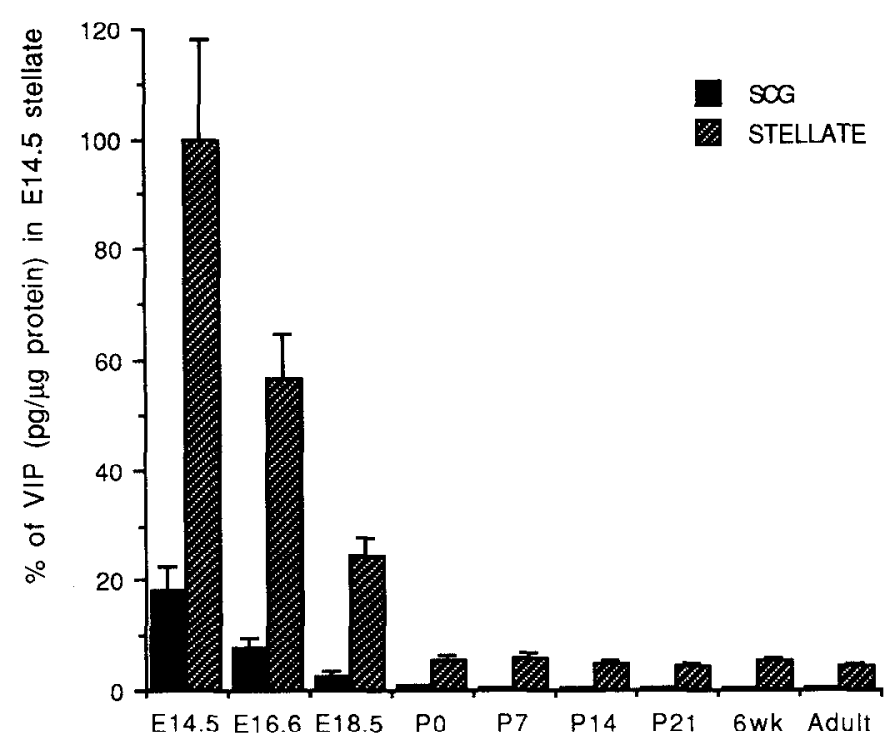

age

Figure 9. VIP-IR concentrations in sympathetic ganglia during embryonic and postnatal development. The concentration of VIP-IR in extracts of SCG and stellate ganglia was measured by RIA. Because sympathetic ganglia are small at these ages, each extract contained ganglia from multiple animals. In both SCG and stellate ganglia the concentration of this peptide decreased rapidly during embryonic development but was relatively stable following birth. At all ages, severalfold more VIP-IR was found in extracts of stellate ganglia than in extracts from SCG extracts. All embryonic values were statistically different from each other, while the only postnatal values that were statistically different were those for P0 and adult SCG (ANOVA, $p<0.05$ ). The numbers of different extracts assayed for different age are as follows: $\mathrm{E} 14.5 \mathrm{SCG}=4$, E16.5 SCG $=6$, E18.5 $\mathrm{SCG}=9$, P0 SCG $=8$, P7adult $\mathrm{SCG}=3, \mathrm{E} 14.5$ stellate $=4, \mathrm{E} 16.5$ stellate $=6, \mathrm{E} 18.5$ stellate $=$ $9, \mathrm{P} 0$ stellate $=8, \mathrm{P} 7$-adult stellate $=3$.

rons expressed immunoreactivity for these peptides. During the same developmental period that the proportion of immunoreactive cells declined, peptide concentrations decreased. In situ hybridization indicated that NPY and VIP mRNA was initially distributed throughout the ganglion, but with time became localized to subsets of cells. While the proportions of neurons containing detectable NPY and VIP immunoreactivity were similar in neonates and adults, the proportion of neurons with NPY and VIP mRNA differed. Although the distribution of ncuropcptidc protcin and mRNA within each ganglion changed during development, NPY was consistently expressed by a similar proportion of neurons in the SCG and stellate ganglion, while VIP was predominantly expressed in the stellate ganglion.

One of the most striking similarities in the development of NPY and VIP was their early expression, not only by neurons, but also by sympathetic precursor cells. Sympathetic precursors are unusual in that they display characteristics of their classical transmitter phenotype prior to their final division, including catecholamine histofluorescence (Cochard et al., 1978, 1979; Rothman et al., 1978) and immunoreactivity for TH and dopamine $\beta$-hydroxylase (DBH; Cochard et al., 1978, 1979; Teitelman et al., 1979; DiCicco-Bloom et al., 1990). Similarly, MAH cells, a clonal cell line derived by retroviral immortali-

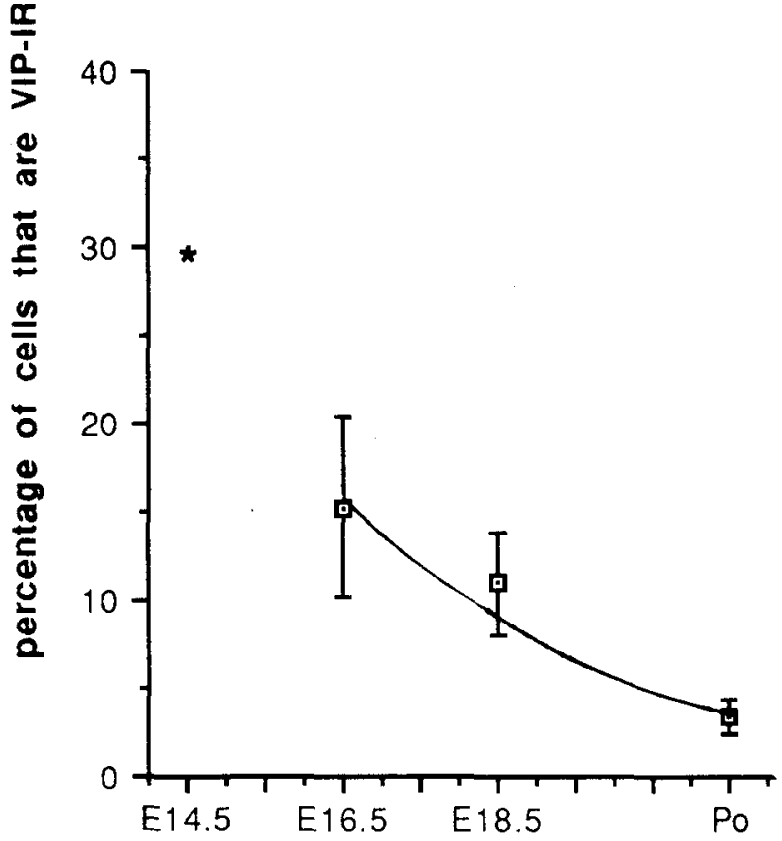

age

Figure 10. Proportion of stellate cells that are VIP-IR during development. The percentage of sympathetic precursors and neurons that were VIP-IR was determined by counting cell profiles from photomicrographs of sections double labeled for TH- and VIP-IR. At E16.5, all VIP-IR were also TH-IR and the total number of cells was determined by counting TH-IR cells; however, at E18.5 and P0, VIP-IR cells were not TH-IR and the total number of cells was determined by adding THIR and VIP-IR cells. To avoid counting cells twice, only profiles containing a nucleus were counted and all sections counted were located at least 35 (E14.5), 70 (E16.5-E18.5), or $100(\mathrm{P} 0) \mu \mathrm{m}$ apart within the ganglion. At least three sections from different regions of the ganglion were counted from each animal. At E14.5 many of the VIP-IR cells were extremely faint, and therefore the proportion of cells was estimated at this time (asterisk); however, with subsequent development, the intensity of immunoreactivity in individual cells increased, allowing us to determine precisely the percentage of VIP-IR cells. The proportion of VIP-IR cells declined until P0 when adult proportions were established. The data for E16.5, E18.5, and P0 were statistically different (ANOVA, $p<0.05$ ). The percentage of immunoreactive neurons was determined from three ganglia at each time point and the number of cells counted in each ganglia ranged from 575 to 1819 . Error bars represent standard deviation.

zation of a sympathoadrenal precursor, contain mRNAs for TH, choline acetyltransferase, and tryptophan hydroxylase (Vandenbergh et al., 1991). These cells also synthesize catecholamines and acetylcholine as do sympathoadrenal precursors isolated from E14.5 adrenal glands.

Many embryonic sympathetic precursors and neurons express phenotypes that they do not display in the adult. Others have described transmitter properties during development that are not detectable in mature neurons; for example, 5-hydroxytryptamine-IR is evident at E12.5 and absent from principal neurons of adult ganglia, and somatostatin-IR is present in many sympathetic neurons at E16.5, but only in rare neurons in adult ganglia (Hokfelt et al., 1977; Soinila et al., 1989; Katz et al., 1992). Similar changes occur in avian sympathetic neurons (Hayashi et al., 1983; Garcia-Arraras et al., 1984; Maxwell et al., 1984; New and Mudge, 1986; Garcia- 
Arraras and Marinez, 1990). We found the proportion of cells that are initially immunoreactive for NPY and VIP is much greater than in the adult (Jarvi et al., 1986; Landis and Fredieu, 1986; DeJonge, Henion and Landis, unpublished observations). A consequence of the expression of multiple transmitter properties by large proportions of precursors and immature neurons is that phenotypes that are mutually exclusive in the adult overlap in the embryo. Thus, VIP is coexpressed with TH and NPY in embryonic stellate cells; neither combination is normally evident in adult neurons (see Elfvin et al., 1993). By birth, however, the proportions of NPY- and VIP-IR neurons resemble those in the adult and NPY and VIP were no longer in the same neurons.

The decrease in the proportion of NPY- and VIP-IR cells and the segregation of the two phenotypes were accompanied by increased immunofluorescence in cells that remained detectably immunoreactive. The number of NPY-IR neurons decreased $40 \%$ and NPY-IR concentration $60 \%$ between E16.5 and P0; in the stellate ganglion, the number of VIP-IR neurons and the concentration of VIP-IR decreased $95 \%$ between E14.5 and P0. Changes in peptide concentration reflect alterations in the number of immunoreactive cells, the concentration of immunoreactivity in those cells, and the changing proportion of ganglionic volume occupied by neurons. In the SCG, glial cells proliferate after E16.5 (Hendry, 1977; Hall and Landis, 1991, 1992), resulting in a smaller proportion of the ganglionic volume being occupied by neurons. This may explain, in part, why the NPY concentration decreased more than the proportion of NPYIR neurons and why the increased peptide concentration suggested by greater immunofluorescence was not reflected in the concentration of peptide immunoreactivity measured by RIA. The developing SCG, like the stellate ganglion, contained VIPIR (Pincus et al., 1990), albeit severalfold less, and the VIP concentration in SCG decreased at the same rate as in stellate ganglia. Despite the presence of VIP-IR detected by RIA, neither immunoreactive cells nor specific hybridization with a VIP mRNA probe was detectable. Since the VIP concentration is higher in E14.5 SCG than P0 stellate ganglia, which contain cells with VIP-IR and VIP mRNA, the simplest explanation is that relatively more cells in the SCG express relatively lower levels of VIP.

While the adult proportions of sympathetic neurons containing NPY- and VIP-IR were established by birth, the distributions of NPY and VIP mRNA were modified postnatally. There is a clear discrepancy in the percentage of neurons with peptideIR and mRNA at P0: $60 \%$ of P0 SCG neurons were NPY-IR but almost all neurons in P0 SCG possessed similar levels of NPY mRNA. Because most NPY-IR neurons were brightly immunofluorescent, we do not believe that this discrepancy results from different sensitivities of the two methods. As rats matured, the level of NPY mRNA was upregulated in some neurons until approximately $60 \%$ of SCG neurons had high grain densities and $40 \%$ had lower grain densities. Similarly, while the proportion of neurons with VIP-IR was similar at P0 and adulthood, the proportion of neurons with VIP mRNA was greater at $\mathrm{P} 0$ than in the adult. Discrepancies between peptide and mRNA levels exist for several neuropeptides (Kilpatrick et al., 1985; Pittius et al., 1985; Howells et al., 1986; Siegel, 1989; Spiegel et al., 1990; Nawa et al., 1991; Watanabe et al., 1991; Tyrrell and Landis, 1994), including NPY (Sabol and Higuchi, 1990; Tyrrell et al., 1992) and VIP (reviewed in Gozes, 1988), and have been attributed to differences in mRNA stability,
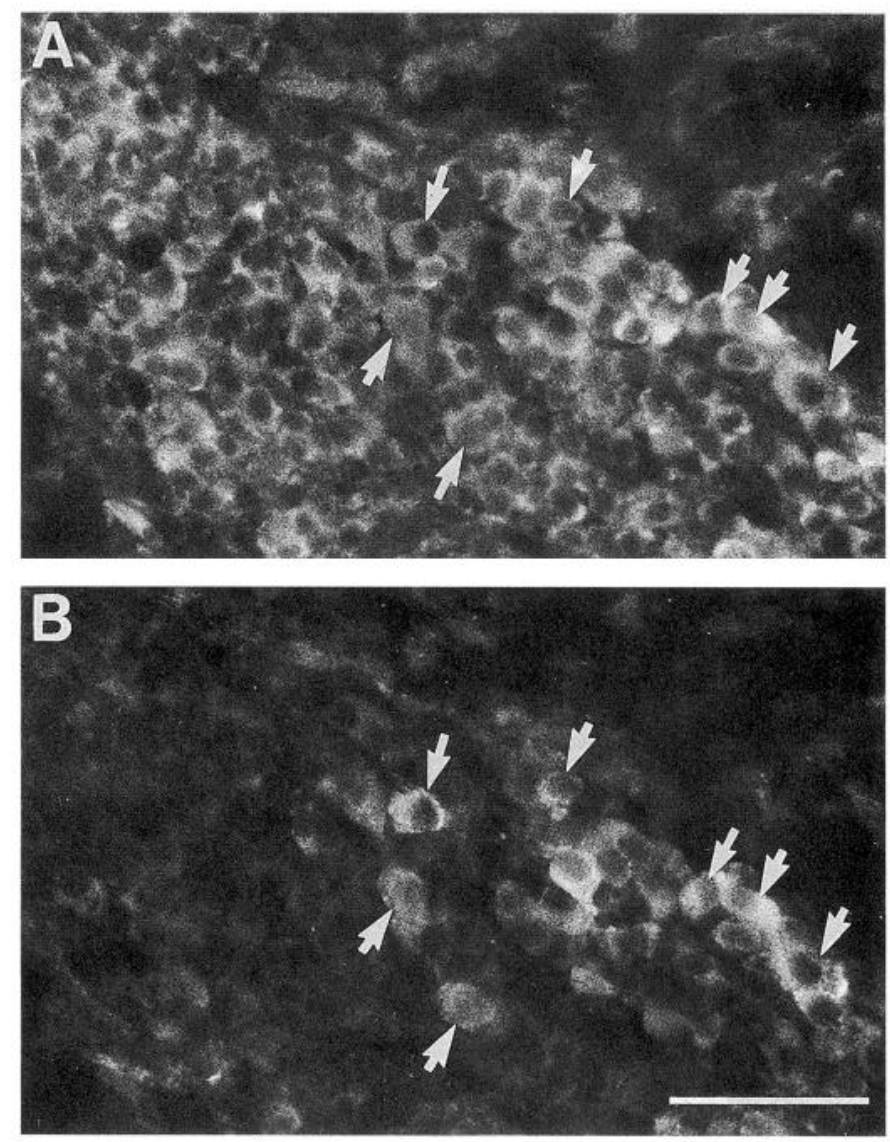

Figure 11. NPY-IR and VIP-IR are colocalized in some stellate neurons during embryonic development. Sections of E16.5 rat sympathetic ganglia were labeled for NPY and VIP. Some cells (arrows) were immunoreactive for both NPY $(A)$ and VIP $(B)$, indicating that these peptides are colocalized at this age. Scale bar, $50 \mu \mathrm{m}$.

translation efficiency, or precursor processing (Birch and Christie, 1986; Gozes et al., 1987; Stachowiak et al., 1988; Kew et al., 1989; Spruce et al., 1990). Whatever the explanation, our results suggest that the mechanisms regulating neuronal peptide content change as the ganglion matures.

Early widespread expression and subsequent restriction of transmitter properties are not restricted to developing sympathetic neurons. Adrenal chromaffin cells and enteric neurons that appear related to sympathetic neurons (Landis and Patterson, 1981; Anderson, 1989; Carnahan et al., 1991) have similar patterns of catecholaminergic and peptidergic expression. For example, twice as many chromaffin cells contain NPY at E15 than do so at birth (Henion and Landis, 1990). In addition, more embryonic than adult chromaffin cells are enkephalin-IR; in other animals, this developmental decrease in enkephalin-IR has been correlated with changes in precursor processing (Coulter et al., 1990; Martinez et al., 1991). Enteric neurons are derived from transiently catecholaminergic cells that express $\mathrm{TH}-$, DBH- and NPY-IR (Baetge et al., 1990). At least some TC cells are mitotic, indicating that TC cells, like sympathoblasts, possess transmitter properties prior to their final division (Teitelman et al., 1978, 1981; Jonakait et al., 1979; Baetge et al., 1990). These characteristics are subsequently lost; mature enteric neurons are not TH- or DBH-IR and only a subset are NPY-IR.

The embryonic restriction of peptidergic phenotypes does not appear to be irreversible. Changes in VIP-IR are induced during 


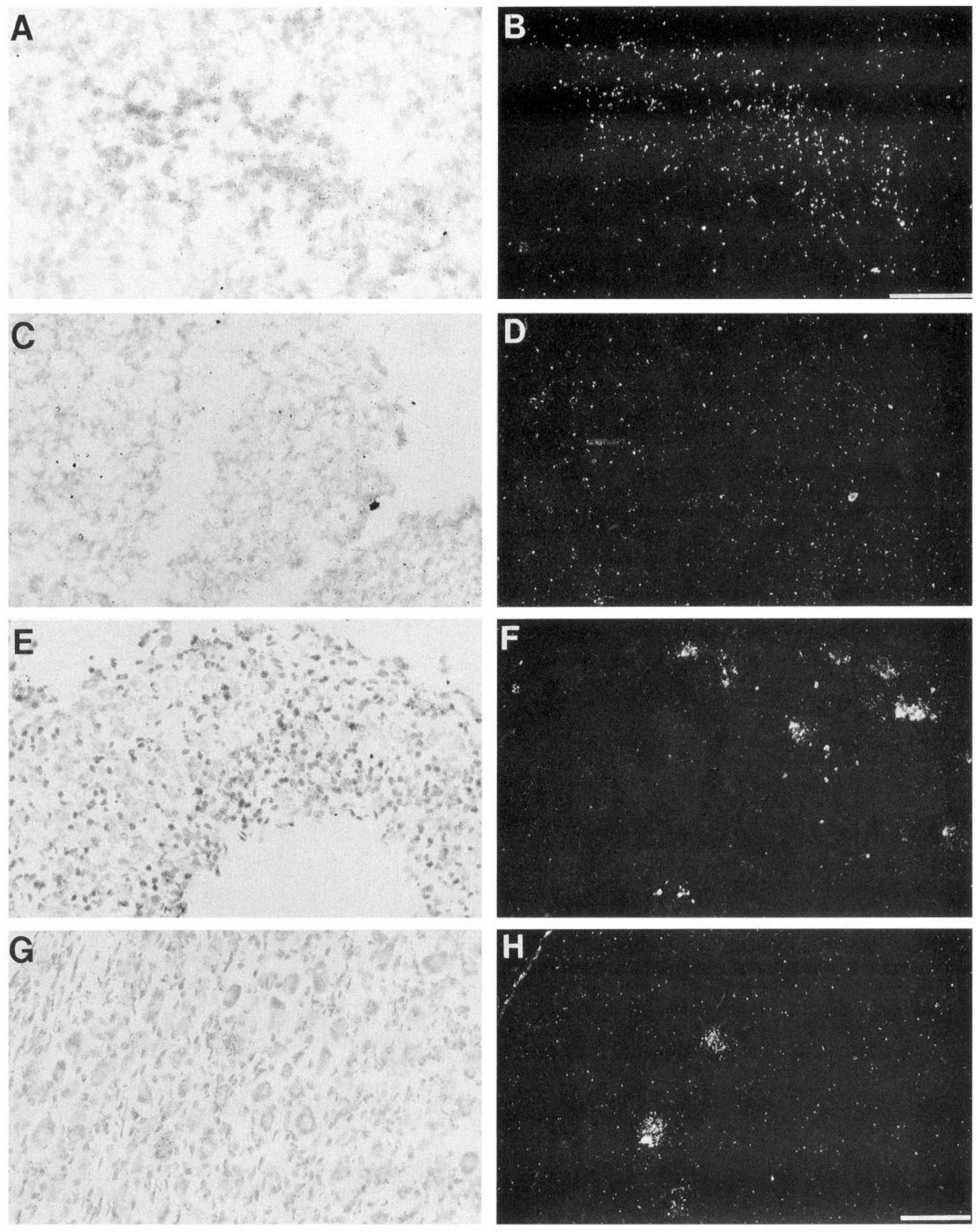

Figure 12. Development of VIP mRNA in sympathetic ganglia. Sections of rat sympathetic ganglia, which had been fixed after sectioning, were examined with bright-field $(A, C, E$, and $G)$ and dark-field microscopy $(B, D, F$, and $H)$ following hybridization with a probe complementary to VIP mRNA. E14.5 stellate ganglion $(A$ and $B)$ had grains specifically located over it; however, E14.5 SCG $(C$ and $D)$ did not. By P0, grains were clearly localized over a subset of stellate neurons $(E$ and $F)$. The proportion of stellate neurons with these grains over them continued to decline postnatally so that in the adult stellate $(G$ and $H$ ) the proportion was about one-half of the P0 value. Scale bars, $50 \mu \mathrm{m}$. 
normal postnatal development and following experimental manipulation. During the second postnatal week, sweat glands induce VIP-IR in TH-IR sympathetic fibers that subsequently become weakly TH-IR (Landis et al., 1988; Schotzinger and Landis, 1990; Schotzinger et al., 1994). While no stellate neurons possess both VIP- and TH-IR at PO or in adulthood, some possess both VIP and TH-IR when sweat gland fibers are immunoreactive for both (Rao, Tyrrell, and Landis, unpublished observations). VIP is also induced in SCG neurons when they are cultured (Nawa and Patterson, 1990; Nawa and Sah, 1990; Garcia-Arraras, 1991; Rao et al., 1992b; Sun et al., 1992, 1994; Zigmond et al., 1992) and if they are axotomized in vivo (HyattSachs et al., 1993; Rao et al., 1993a,c). Somatostatin, transiently expressed by embryonic sympathetic neurons (Katz et al., 1992), is also induced with culture (Kessler, 1985; Nawa and Sah, 1990; Rao et al., 1992b). It is unclear at present whether these peptide inductions represent reexpression of an embryonic phenotype or de novo expression.

There are similarities and differences in the development of NPY and VIP expression in rat as compared to chick and frog. NPY-IR appeared after TH-IR in rat, chick, and bullfrog sympathetic ganglia and was expressed in equivalent proportions of cells in different sympathetic ganglia in both rat and bullfrog (Stofer and Horn, 1990; Garcia-Arraras et al., 1992). In contrast to rat, the proportion of NPY-IR cells was initially small in chick and bullfrog ganglia and then increased. Further, expression of NPY was attributed to postmitotic neurons in frog (Stofer and Horn, 1990, 1993). NPY levels in rat and chick sympathetic ganglia decrease following a peak during embryogenesis; in chick, however, this decrease occurs later than in rat and is not statistically significant (Garcia-Arraras et al., 1992). The developmental expression of VIP also differed in chick and rat sympathetic ganglia. VIP is first detected in a small number of cells and then both the proportion of VIP-IR cells and the concentration of VIP-IR increase (Hayashi et al., 1983; New and Mudge, 1986; Garcia-Arraras et al., 1987). In contrast, we found VIP was first expressed in a relatively large proportion of cells and both the proportion of these cells and the VIP concentration subsequently decreased.

Because of our knowledge of sympathetic neuron development, candidate mechanisms for the induction and subsequent regulation of NPY and VIP can be assessed for their likelihood. Since the developmental patterns of expression for NPY and VIP differ in a number of respects, distinct mechanisms are likely to regulate aspects of their expression. In principal, the induction of peptide expression could be influenced by lineage, birthdate, environmental cucs along the migratory route, factors within the local ganglionic environment, preganglionic signals, and target-derived signals. Since NPY was present shortly after gangliogenesis in virtually all precursors and neurons, it is unlikely that its expression was initially induced by either preganglionic innervation or target contact. NPY-IR was first detected when preganglionic fibers have begun to appear in sympathetic ganglia but before functional connections are made (Rubin, 1985 b,c). NPY-IR was also present in dividing precursor cells which possess only short processes (Anderson, 1986; DiCiccoBloom et al., 1990) that are unlikely to have extended outside the ganglion and to have contacted targets. Further, NPY-IR is present in fibers when they reach targets (Allen et al., 1989; Anderson and McLachlan, 1991; Li and Walsh, 1991; Tsai et al., 1992). Based on the very early expression of NPY and uniform coexpression with TH-IR, a common signal may induce

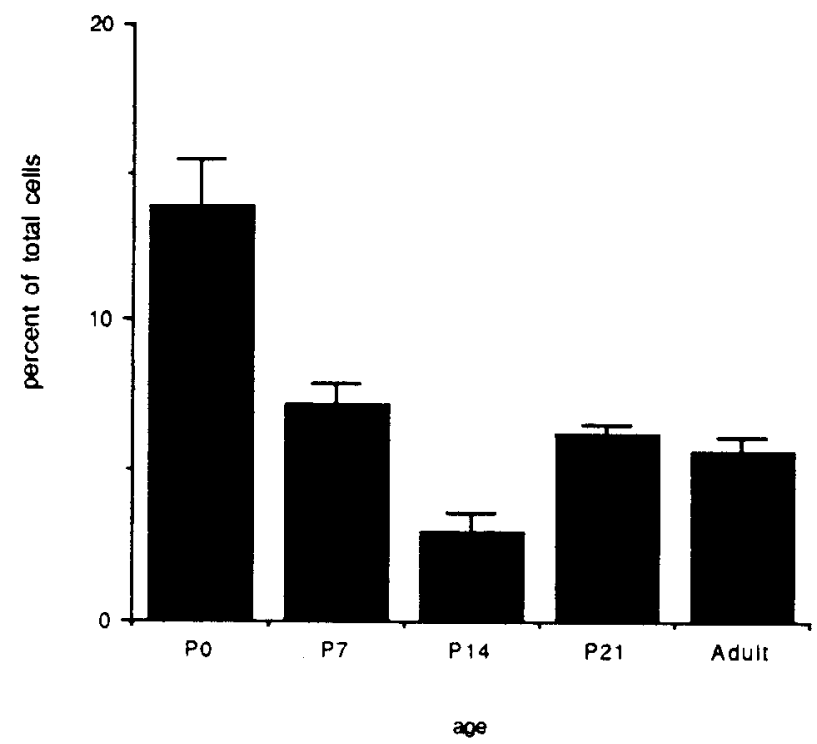

Figure 13. Postnatal development of VIP mRNA in stellate ganglia. The percentage of stellate neurons with specific grain densities following hybridization with a probe complementary to VIP mRNA was determined by counting neurons using bright- and dark-field microscopy. The percentage of neurons with VIP mRNA decreased during the first 2 postnatal weeks and then increased. Three ganglia were examined at each age. Data from P0, P7, and P14 are all statistically different from each other, while P7, P21, and adult ganglia are not. Data from P14 are statistically different from P21 but not adult ganglia (ANOVA, $p<$ $0.05)$.

both catecholaminergic properties and NPY. Consistent with the hypothesis of a common inductive signal are the findings that NPY and TH are uniformly coexpressed by TC cells in the developing gut, which are proposed as members of the sympathoadrenal lineage (Baetge et al., 1990; Carnahan et al., 1991; Lo et al., 1991). Catecholaminergic properties are believed to be induced in sympathoadrenal precursors during migration by ventral neural tube/notochord and somitic mesenchyme (Cohen, 1972; Norr, 1973; Teillet et al., 1978; Howard and BronnerFraser, 1985, 1986; Coulombc and Bronner-Fraser, 1986). The inductive signal remains to be defined but an intermediary step may be induction of MASH 1, a rat homolog of Drosophila achaete-scute (Johnson et al., 1990; Lo et al., 1991). Although NPY-IR appears later than catecholaminergic properties, this lag could reflect differences in the cellular mechanisms required for expression of the two properties.

Since VIP-IR is expressed later than NPY, in one but not both ganglia, and only in a subset of TH-IR cells, the mechanisms regulating its initial expression are likely to differ from those inducing catecholaminergic properties and NPY. VIP could be induced in sympathetic precursors that form ganglia in the thoracic regions by adjacent tissues. As described below, several factors induce VIP expression in sympathetic neurons and one or more of these, differentially distributed in the embryo, could be responsible. Alternatively, the differential expression of VIP in SCG and stellate ganglion could reflect an inhibitory influcnce of the tissues SCG precursors encounter as they migrate to the cervical region. VIP-IR is variable in intensity as soon as it appears, and how heterogeneous induction of VIP-IR is achieved is unclear. One mechanism that might account for the uneven appearance of VIP-IR in neighboring cells is differential modulation of VIP expression by preganglionic activation after in- 
duction. Functional connections between preganglionic fibers and the SCG exist at E13.5 (Rubin, 1985c) $1 \mathrm{~d}$ before VIP-IR appears and depolarization increases the expression of VIP-IR in neonatal sympathetic neurons in vitro (Rao et al., 1992).

The appearance of VIP in embryonic sympathetic precursors and neurons observed in the present study contrasts with previous findings of postnatal VIP induction in sweat gland innervation. In this case, VIP expression is induced by the target tissue. VIP-IR appears in developing sweat gland innervation after axons have contacted the target for a week (Landis et al., 1988). Its appearance in the sweat gland innervation requires interaction with glands, and sweat glands induce VIP in neurons that would not normally innervate them or contain VIP (Schotzinger and Landis, 1990; Stevens and Landis, 1990; Schotzinger et al., 1994). Differentiation factor(s) present in footpad extracts has been partially characterized and it will be of interest to determine whether the same differentiation factors play a role in both embryonic and postnatal inductions (Rao and Landis, 1990; Rao et al., 1992c, 1993; Rohrer, 1992).

The mechanisms responsible for restriction of peptide expression to a fraction of the neurons that initially expressed it are as important for shaping the final phenotype as those responsible for the initial induction. Our analysis of NPY and VIP suggests that restriction involves both decreased and increased expression in distinct populations of cells and that this process, which begins in late embryogenesis, continues into postnatal development. During late embryogenesis, immunoreactivity for both neuropeptides increases in some neurons while decreasing in others. Similarly, at birth, in the SCG, sympathetic neurons appear to constitute a single population with respect to NPY mRNA but two distinct populations are present in adult ganglia. Since NPY expression is correlated in adult animals with innervation of particular target tissues including iris, pineal, and vasculature (Hokfelt et al., 1980; Lundberg et al., 1982; Bjorklund et al., 1985; Schon et al., 1985; Hokfclt, 1991), it seems likely that target tissues play a role in this process, either by target-specific maintenance or target-specific suppression. Consistent with this, neurons begin to segregate into populations that are more or less NPY-IR at E16.5, when at least some neurons have established terminal plexuses in target tissues (Rubin, 1985a). Since cultures of sympathetic precursor cells isolated from E14.5 SCG acquire a normal complement of NPYIR and NPY-negative neurons, at least in culture, signals from the local ganglionic environment are sufficient and neither afferent innervation nor target signals are required for restriction (Hall and MacPhedran, 1994). Glial precursors proliferate when NPY is restricted to a subset of TH-IR cells (Hall and Landis, 1992) and the absence of non-neuronal cells in SCG cultures increases the proportion of NPY-IR neurons (Hall and MacPhedran, 1994). A similar mechanism has been postulated for the restriction of TH-IR in cranial sensory neurons (Fan and Katz, 1993).

A number of the mechanisms invoked to regulate peptide expression in sympathetic neurons during development involve environmental signals. Several cytokines and trophic factors influence peptide expression and represent candidates. Both leukemia inhibitory factor (LIF) and ciliary neurotrophic factor (CNTF) decrease NPY-IR and increase VIP-IR in sympathetic neurons in vitro (Ernsberger et al., 1989; Nawa and Patterson, 1990; Nawa et al., 1991; Rao et al., 1992b; Sun et al., 1994) and another cytokine, oncostatin M, causes VIP induction (Rao et al., 1992a; Symes et al., 1992). Furthermore, nerve growth factor (NGF) increases NPY in PC12 cells (Allen et al., 1984, 1987; Sabol and Higuchi, 1990). Several lines of evidence suggest that developing sympathetic neurons have access to these factors. Medium conditioned by non-neuronal cells from sympathetic ganglia contains I IF (Sun et al., 1994) and LIF mRNA is present in rat footpads containing sweat glands (Yamamori, 1991). NGF and NGF mRNA are present in sympathetic targets during development (Korsching and Thoenen, 1983, 1988; Shelton and Reichardt, 1984; Davies et al., 1987). In addition to differentiation factors already characterized, additional peptidergic factors present in tissue extracts and conditioned media remain to be identified (Nawa and Patterson, 1990; Nawa and Sah, 1990; Rao et al., 1992c; Rohrer, 1992; Fann and Patterson, 1993) and peptidergic factors identified in other systems, such as the somatostatin-inducing factor for ciliary neurons (Coulombe and Nishi, 1991; Coulombe et al., 1993), need to be assessed for their effects on sympathetic neurons. Our studies imply that developmental changes in peptide expression are not likely to be the result of any single factor. While the mechanisms that regulate neuropeptide expression appear to be complex, this should not be surprising, considering the complexity of the environment in which neurons develop.

\section{References}

Adler J, Schleifer LS, Black IB (1989) Partial purification and characterization of a membrane-derived factor regulating neurotransmitter phenotypic expression. Proc Natl Acad Sci USA 86:1080-1083.

Allen GL, Wilson FJ, MacDonald GJ (1989) Neuropeptide Y-containing nerves in rat gonads: sex difference and development. Biol Reprod 40:371-378

Allen JM, Tischler AS, Lee YC, Bloom SR (1984) Neuropeptide Y (NPY) in PC12 pheochromocytoma cultures: responses to dexamethasone and nerve growth factor. Neurosci Lett 46:291-296.

Allen JM, Martin JB, Heinrich G (1987) Neuropeptide Y gene expression in PC12 cells and its regulation by nerve growth factor: a model for developmental regulation. Mol Brain Res 3:39-43.

Anderson CR, McLachlan EM (1991) The time course of the development of the sympathetic innervation of the vasculature of the rat tail. J Auton Nerv Syst 35:117-132.

Anderson DJ (1986) A bipotential neuroendocrine precursor whose choice of cell fate is determined by NGF and glucocorticoids. Cell 47:1079-1090.

Anderson DJ (1989) The neural crest cell lineage problem: neuropoiesis? Neuron 3: 1-12.

Baetge G, Pintar JE, Gershon MD (1990) Transiently catecholaminergic (TC) cells in the bowel of the fetal rat: precursors of noncatecholaminergic enteric neurons. Dev Biol 141:353-380.

Baraniuk JN, Kaliner M (1991) Neuropeptides and nasal secretion. Am J Physiol 261:L223-L235.

Birch MP, Christie DL (1986) Characterization of the molecular forms of procnkcphalin in bovinc adrenal medulla and rat adrenal, brain, and spinal cord with a site directed antiserum. J Biol Chem 261: 12213-12221.

Bjorklund H, Hokfelt T, Goldstein M, Terenius L, Olson L (1985) Appearance of the noradrenergic markers tyrosine hydroxylase and neuropeptide $\mathrm{Y}$ in cholinergic nerves of the iris following sympathectomy. J Neurosci 5:1633-1643.

Black IB, Mytilineou C (1976) Trans-synaptic regulation of the development of end organ innervation by sympathetic neurons. Brain Res 101:503-521.

Bleakman D, Miller RJ, Colmers WF (1992) Actions of neuropeptide $Y$ on the electrophysiological properties of nerve cells. In: The biology of neuropeptide $\mathrm{Y}$ and related peptides (Colmers WF, Wahlestedt C, eds), pp 241-267. Totowa, NJ: Humana.

Bratveit M, Helle KB (1991) Inhibition of VIP and atriopeptin II on the field stimulation evoked release of ${ }^{3} \mathrm{H}$ noradrenaline in the rat portal vein. Regul Pept 33:331-337.

Bress WH, Flannery BP, Teukolsky SA, Vetterling WT (1989) Numerical recipes in Pascel (FORTRAN or C). The art of scientific computing. Cambridge: Cambridge UP. 
Carnahan JF, Anderson DJ, Patterson PH (1991) Evidence that enteric neurons may derive from the sympathoadrenal lineage. Dev Biol 148: 552-561.

Christie GA (1962) Developmental stages in somite and post-somite rat embryos, based on external appearance, and including some features of the macroscopic development of the oral cavity. J Morphol 114:263-286.

Cochard P, Goldstein M, Black IB (1978) Ontogenetic appearance and disappearance of tyrosine hydroxylase and catecholamines in the rat cmbryo. Proc Natl Acad Sci USA 75:2986-2990.

Cochard P, Goldstein M, Black IB (1979) Initial development of the noradrenergic phenotype in autonomic neuroblasts of the rat embryo in vivo. Dev Biol 71:100-114.

Cohen AM (1972) Factors directing the expression of sympathetic nerve traits in cells of neural crest origin. J Exp Zool 179:167-182.

Coulombe JN, Bronner-Fraser M (1986) Cholinergic neurons acquire adrenergic neurotransmitters when transplanted into an embryo. $\mathrm{Na}-$ ture 324:569-572.

Coulombe JN, Nishi R (1991) Stimulation of somatostatin expression in developing ciliary ganglion neurons by the cells of the choroid layer. J Neurosci 11:553-562.

Coulombe JN, Schwall R, Parent AS, Eckenstein FP, Nishi R (1993) Induction of somatostatin immunoreactivity in cultured ciliary ganglion neurons by activin in choroid cell-conditioned medium. Neuron 10:899-906.

Coulter CL, Browne CA, McMillen IC (1990) The molecular weight profile of enkephalin-containing peptides in the sheep adrenal gland changes during development. Endocrinology 127:330-336.

Davies AM, Bandtlow C, Heumann R, Korsching S, Rohrer H, Thoenen $\mathrm{H}$ (1987) Timing and site of nerve growth factor synthesis in developing skin in relation to innervation and expression of the receptor. Nature 326:353-358.

DiCicco-Bloom E, Townes-Anderson E, Black IB (1990) Neuroblast mitosis in dissociated culture: regulation and relationship to differentiation. J Cell Biol 1 10:2073-2086.

Dunning BE, Ahren B, Bottcher G, Sundler F, Taborsky GJ (1987) The presence and actions of NPY in the canine endocrine pancreas. Rcgul Pcpt 18:253-265.

Elfvin L, Lindh B, Hokfelt T (1993) The chemical neuroanatomy of sympathetic ganglia. Annu Rev Neurosci 16:471-507.

Ernsberger U, Sendtner M, Rohrer H (1989) Proliferation and differentiation of embryonic chick sympathetic neurons: effects of ciliary neurotrophic factor. Neuron 2:1275-1284.

Fan G, Katz D (1993) Non-neuronal cells inhibit catecholaminergic differentiation of primary sensory neurons: role of leukemia inhibitory factor. Development 118:83-93.

Fann M, Patterson PH (1993) A novel approach to screen for cytokine effects on neuronal gene expression. J Neurochem 61:1359-1355.

Garcia-Arraras J, Chanconie M, Fontaine-Perus J (1984) In vivo and in vitro development of somatostatin-like immunoreactivities in the peripheral nervous system of quail embryos. J Neurosci 4:1549-1558.

Garcia-Arraras J, Chanconie M, Ziller C, Fauquet M (1987) In vivo and in vitro expression of vasoactive intestinal polypeptide-like immunoreactivity by neural crest derivatives. Dev Brain Res 33:255265.

Garcia-Arraras J, Lugo-Chinchilla AM, Chevere-Colon I (1992) The expression of neuropeptide $\mathrm{Y}$ immunoreactivity in the avian sympathoadrenal system conforms with two models of coexpression development for neurons and chromaffin cells. Development 115:617627.

Garcia-Arraras JE (1991) Modulation of neuropeptide expression in avian embryonic sympathetic cultures. Dev Brain Res 60:19-27.

Garcia-Arraras JE, Marinez R (1990) Developmental expression of serotonin-like immunoreactivity in the sympathoadrenal system of the chicken. Cell Tissue Res 262:363-372.

Giloh H, Sedat JW (1982) Fluorescence microscopy: reduced photobleaching of rhodamine and fluorescein protein conjugates by $N$-propyl gallate. Science 217:1252-1255.

Gozes I (1988) Biosynthesis and regulation of expression: the vasoactive intestinal peptide gene. In: Vasoactive intestinal peptide and related peptides (Said SM, Muh V, eds). New York: New York Academy of Sciences.

Gozes I, Giladi E, Shani Y (1987) Vasoactive intestinal peptide gene: putative mechanism of information storage at the mRNA level. $J$ Neurochem 48:1136-1141.
Hall AK, Landis SC (1991) Early commitment of precursor cells from the rat superior cervical ganglion to neuronal or nonneuronal fates. Neuron 6:741-752.

Hall AK, Landis SC (1992) Division and migration of satellite glia in the embryonic rat superior cervical ganglion. J Neurocytol 21:635647.

Hall AK, MacPhedran SE (1994) Expression of neuropeptide $Y$ in neurons derived from sympathetic precursors does not require target tissue contact but is influenced by cell lineage. Dev Biol, in press.

Hayashi M, Edgar D, Thoenen H (1983) The development of substance $\mathbf{P}$, somatostatin and vasoactive intestinal polypeptide in sympathetic and spinal sensory ganglia of the chick embryo. Neuroscience 10:31-39.

Hendry IA (1977) Cell division in the developing sympathetic nervous system. J Neurocytol 6:299-309.

Henion PD, Landis SC (1990) Asynchronous appearance and topographic segregation of neuropeptide-containing cells in the developing rat adrenal medulla. J Neurosci 10:2886-2896.

Hokfelt T (1991) Neuropeptides in perspective: the last ten years. Neuron 7:867-879.

Hokfelt T, Elfvin L, Schultzberg M, Fuxe K, Said SI, Mutt V, Goldstein M (1977a) Immunohistochemical evidence of vasoactive intestinal polypeptide-containing neurons and nerve fibers in sympathetic ganglia. Ncuroscience 2:885-896.

Hokfelt T, Elfvin LG, Elde R, Schultzberg M, Goldstein M, Luft R (1977b) Occurrence of somatostatin-like immunoreactivity in some peripheral sympathetic noradrenergic neurons. Proc Natl Acad Sci USA 74:3587-3591.

Hokfelt T, Johansson O, Ljungdahl A, Lundberg JM, Schultzberg M (1980) Peptidergic neurons. Nature 284:515-521.

Howard MJ, Bronner-Fraser M (1985) The influence of neural tubederived factors on the differentiation of neural crest cells in vitro. I. Histochemical study on the appearance of adrenergic cells. J Neurosci 5:3302-3309.

Howard MJ, Bronner-Fraser M (1986) Neural tube-derived factors influence differentiation of neural crest cells in vitro: effects on activity of neurotransmitter biosynthetic enzymes. Dev Biol 117:45-54.

Howells RD, Kilpatrick DL, Bailcy LC, Noe M, Udenfriend S (1986) Proenkephalin mRNA in heart. Proc Natl Acad Sci USA 83:19601963.

Hyatt-Sachs H, Schreiber RC, Bennett TA, Zigmond RE (1993) Phenotypic plasticity in adult sympathetic ganglia in vivo: effects of deafferentation and axotomy on the expression of vasoactive intestinal peptide. J Neurosci 13:1642-1653.

Jarvi R, Helen P, Pelto-Huikko M, Hervonen A (1986) Neuropeptide Y- (NPY-) like immunoreactivity in rat sympathetic neurons and small granule containing cells. Neurosci Lett 67:223-227.

Johnson J, Birren S, Anderson D (1990) Two rat homologues of Drosophila acaete-scute specifically expressed in neuronal precursors. Nature 346:858-861.

Jonakait GM, Wolf J, Cochard P, Goldstein M, Black IB (1979) Selective loss of noradrencrgic phenotypic characters in neuroblasts of the rat embryo. Proc Natl Acad Sci USA 76:4683-4686.

Katz DM, He H, White M (1992) Transient expression of somatostatin peptide is a widespread feature of developing sensory and sympathetic neurons in the embryonic rat. J Neurobiol 23:855-870.

Kessler JA (1985) Differential regulation of peptide and catecholamine characters in cultured sympathetic neurons. Neuroscience 15:827839.

Kew D, Jin DF, Kim F, Laddis T, Kilpatrick DL (1989) Translational status of proenkephalin mRNA in the rat reproductive system. Mol Endocrinol 3:1191-1196.

Kilpatrick DL, Howells RD, Noe M, Bailey CL, Udenfriend S (1985) Expression of preproenkephalin-like mRNA and its peptide products in mammalian testis and ovary. Proc Natl Acad Sci USA 82:74677469 .

Korsching S, Thoenen H (1983) Nerve growth factor in sympathetic ganglia and corresponding target organs of the rat: correlation with density of sympathetic innervation. Proc Natl Acad Sci USA 80: 3513-3516.

Korsching S, Thoenen H (1988) Developmental changes of nerve growth factor levels in sympathetic ganglia and their target organs. Dev Biol 126:40-46.

Kummer W, Heym C (1988) Neuropeptide distribution in the cervicothoracic paravertebral ganglia of the cat with particular reference to 
calcitonin gene-related peptide immunoreactivity. Cell Tissue Res 252:463-471.

Landis S, Damboise (1986) Neuron birthdays in the paravertebral sympathetic chain of the rat. Anat Rec Abstr 214:71 A.

Landis SC, Fredieu JR (1986) Coexistence of calcitonin gene-related peptide and vasoactive intestinal peptide in cholinergic sympathetic innervation of rat sweat glands. Brain Res 377:177-181.

Landis SC, Keefe D (1983) Evidence for neurotransmitter plasticity in vivo: developmental changes in properties of cholinergic sympathetic neurons. Dev Biol 98:349-372.

Landis SC, Patterson PH (1981) Neural crest lineages. Trends Neurosci $4: 172-175$.

Landis SC, Siegel RE, Schwab M (1988) Evidence for neurotransmitter plasticity in vivo. II. Immunocytochemical studies of rat sweat gland innervation during development. Dev Biol 126:129-140.

Larhammar D, Ericsson A, Persson H (1987) Structure and expression of the rat neuropeptide $Y$ gene. Proc Natl Acad Sci USA 84:20682072.

Lefebvre RA, DeVriese A, Smits GJ (1992) Influence of vasoactive intestinal polypeptide and NG-nitro-L-arginine methyl ester on cholinergic neurotransmission in the rat fundus. Eur J Pharmacol 221: 235-242.

Li Y, Walsh MG (1991) Tyrosine hydroxylase and neuropeptide-Y immunoreactivity in pineal glands developing in situ and in pineal grafts. Cell Tissue Res 264:515-526.

Lindh B, Lundberg JM, Hokfelt. T, Flfvin L, Fahrenkurg J, Fischer J (1987) Coexistence of CGRP-IR and VIP-like immunoreactivities in a population of neurons in the cat stellate ganglia. Acta Physiol Scand 131:475-476.

Lindh B, Lundberg J, Hokfelt T (1989) NPY-, galanin-, VIP/PHI-, CGRP- and substance P-immunoreactive neuronal subpopulations in cat autonomic and sensory ganglia and their projections. Cell Tissue Res 256:259-273.

Lo L, Johnson J, Wuenschell C, Saito T, Anderson D (1991) Mammalian acaete-scute homologue $l$ is transiently expressed by spatially restricted subsets of early neuroepithelial and neural crest cells. Genes Dev 5:1524-1537.

Lundberg JM, Hokfelt T, Schultzberg M, Uvnas WK, Kohler C, Said SM (1979) Occurrence of vasoactive intestinal polypeptide (VIP)like immunoreactivity in certain cholinergic neurons of the cat. Evidence from combined immunohistochemistry and acetylcholinesterase staining. Neuroscience 4:1539-1559.

Lundberg JM, ^nggard A, Fahrenkurg J, Hokfelt T, Mutt V (1980) Vasoactive intestinal polypeptide in cholinergic neurons of exocrine glands: functional significance of coexisting transmitters for vasodilation and secretion. Proc Nall Acad Sci USA 77:1651-1655.

Lundberg JM, Hokfelt T, Angaard A, Terenius L, Elde R, Markey K, Goldstein M (1982a) Organizational principles in the peripheral nervous system: subdivisions by coexisting peptides (somatostatin, avian pancreatic polypeptide and vasoactive intestinal peptide-like materials). Proc Natl Acad Sci USA 79:1303-1307.

Lundberg JM, Terenius L, Hokfelt T, Martling CR, Tatemoto K, Mutt V, Polak J, et al. (1982b) Neuropeptide Y (NPY)-like immunoreactivity in peripheral noradrenergic neurons and effects of NPY on sympathetic function. Acta Physiol Scand 1 16:477-480.

Lundberg JM, Franco-Cereceda A, Lacroix J, Pernow J (1990) Neuropeptide $Y$ and sympathetic neurotransmission. Ann NY Acad Sci 116:166-174.

Martinez A, Padbury J, Chappell B, Habib D, Thio S, Burnell E (1991) Maturational changes in expression of enkephalin peptides in adrenal and extra-adrenal tissue of fetal and adult rabbits. Brain Res Bull 26: 935-940.

Maxwell GD, Sietz PD, Chenard PH (1984) Development of somatostatin-like immunoreactivity in embryonic sympathetic ganglia. J Neurosci 4:576-584.

Miller MW, Nowakowski RS (1988) Use of bromodeoxyuridine-immunohistochemistry to examine the proliferation, migration and time of origin of cells in the central nervous system. Brain Res 457:44-52.

Nawa H, Patterson PH (1990) Separation and partial characterization of neuropeptide-inducing factors in heart cell conditioned medium. Neuron 4:269-277.

Nawa H, Sah DWY (1990) Different biological activities in conditioned media control the expression of a variety of neuropeptides in cultured sympathetic neurons. Neuron 4:279-287.

Nawa H, Nakanishi S, Patterson PH (1991) Recombinant cholinergic differentiation factor (leukemia inhibitory factor) regulates sympa- thetic neuron phenotype by alterations in the size and amounts of neuropeptide mRNAs. J Neurochem 56:2147-2150.

New HV, Mudge AW (1986) Distribution and ontogeny of SP, CGRP, SOM, and VIP in chick sensory and sympathetic ganglia. Dev Biol $116: 337-346$.

Nilsson C, Kannisto P, Lindvall-Axelsson M, Owman C, Rosengren E (1990) The neuropeptides vasoactive intestinal polypeptide, peptide histidine isoleucine and neuropeptide $\mathrm{Y}$ modulate ${ }^{3} \mathrm{H}$ noradrenaline release from sympathetic nerves in the choroid plexus. Eur $\mathrm{J}$ Pharmacol 181:247-252.

Nishizawa M, Hayakawa Y, Yanaihara N, Okamoto H (1985) Nucleotide sequence divergence and functional constraint in VIP precursor mRNA evolution between human and rat. FEBS Lett 183:5559.

Norr S (1973) In vitro analysis of sympathetic neuron differentiation from chick neural crest cells. Dev Biol 34:16-38.

Owan C (1990) Peptidergic vasodilator nerves in the peripheral circulation and in the vascular beds of the heart and brain. Blood Vessels 27:73-93.

Pincus DW, DiCicco-Bloom E, Black IB (1990) Vasoactive intestinal peptide regulates mitosis, differentiation and survival of cultured sympathetic neuroblasts. Nature 343:564-567.

Pittius CW, Kley N, Loeffler JP, Hollt V (1985) Quantitation of proenkephalin A messenger RNA in bovine brain, pituitary and adrenal medulla: correlation between mRNA and peptide levels. EMBO J 4:1257-1260.

Przywara DA, Bhave SV, Bhave A, Wakade TD, Wakade AR (1991) Dissociation between intracellular $\mathrm{Ca}^{2+}$ and modulation of ${ }^{3} \mathrm{H}$ noradrenaline release in chick sympathetic neurons. J Physiol (Lond) 437:201-220.

Rao MS, Landis SC (1990) Characterization of a target derived neuronal cholinergic differentiation factor. Neuron 5:899-910.

Rao MS, Symes A, Shoyab, Fink S, Landis S (1992a) Onco-M regulates VIP expression in a human neuroblastoma cell line. Neuroreport 3:865-868.

Rao MS, Tyrrell S, Landis SC, Patterson PH (1992b) Effects of ciliary neurotrophic factor (CNTF) and depolarization on neuropeptide expression in cultured sympathetic neurons. Dev Biol 150:281-293.

Rao M, Patterson PH, Landis SC (1992c) Multiple cholinergic differentiation factors are present in footpad extracts: comparison with known cholinergic factors. Development 116:731-744.

Rao M, Sun Y, Escary J, Perreau J, Tresser S, Patterson P, Zigmond $R$, et al. (1993a) Leukemia inhibitory factor mediates an injury response but not a target-directed developmental transmitter switch in sympathetic neurons. Neuron 11:1175-1185.

Rao MS, Sun Y, Vaidyanathan U, Landis SC, Zigmond RE (1993b) Regulation of substance $P$ is similar to that of vasoactive intestinal peptide after axotomy or explantation of the rat superior cervical ganglion. J Neurobiol 24:571-580.

Rohrer H (1992) Cholinergic neuronal differentiation factors: evidence for the presence of both CNTF-like and non-CNTF-like factors in developing foot pad. Development 114:689-698.

Rothman TP, Gershon MD, Holtzer H (1978) The relationship of cell division to the acquisition of adrenergic characteristics by developing sympathetic ganglion cell precursors. Dev Biol 65:322-341.

Rubin E (1985a) Development of the rat superior cervical ganglion: ganglion cell maturation. J Neurosci 5:673-684.

Rubin E (1985b) Development of the rat superior cervical ganglion: ingrowth of preganglionic axons. J Neurosci 5:685-696.

Rubin E (1985c) Development of the rat superior cervical ganglion: initial stages of synapse formation. J Neurosci 5:697-704.

Sabol SL, Higuchi H (1990) Transcriptional regulation of the neuropeptide $\mathrm{Y}$ gene by nerve growth factor: antagonism by glucocorticoids and potentiation by adenosine $3^{\prime}, 5^{\prime}$-monophosphate and phorbol ester. Mol Endocrinol 4:384-392.

Sasek CA, Zigmond RE (1989) Localization of vasoactive intestinal peptide- and peptide histidine isoleucine amide-like immunoreactivities in the rat superior cervical ganglion and its nerve trunks. J Comp Neurol 280:522-532.

Schon F, Allen J, Yeats J, Allen Y, Ballesta J, Polak J, Kelly J, et al. (1985) Neuropeptide $Y$ innervation of the rodent pineal gland and cerebral blood vessels. Neurosci Lett 57:65-71.

Schotzinger R, Landis SC (1990) Acquisition of cholinergic and peptidergic properties by the sympathetic innervation of rat sweat glands requires interaction with normal target. Neuron 5:91-100.

Schotzinger R, Yin X, Landis SC (1994) Induction of a novel, target- 
appropriate transmitter phenotype following transplantation. J Neurobiol, in press.

Shelton DL, Reichardt LF (1984) Expression of the beta-nerve growth factor gene correlates with the density of sympathetic innervation of effector organs. Proc Natl Acad Sci USA 81:7951-7955.

Siegel RE (1989) Localization of neuronal mRNAs by hybridization histochemistry. Methods Neurosci 1:136 150.

Smolen AJ, Raisman G (1980) Synapse formation in the rat superior ganglion during normal development and after neonatal deafferentation. Brain Res 181:315-323.

Soinila S, Ahonen M, Lahtinen T, Happola O (1989) Developmental changes in 5-hydroxytryptamine immunoreactivity of sympathetic cells. Int J Dev Neurosci 7:553-563.

Spiegel K, Wong V, Kessler JA (1990) Translational regulation of somatostatin in cultured sympathetic neurons. Neuron 4:303-311.

Spruce BA, Curtis R, Wilkin GP, Glover DM (1990) A neuropeptide precursor in cerebellum: proenkephalin exists in subpopulations of both neurons and astrocytes. F.MBO J 9:1787-1795.

Stachowiak MK, Lee PHK, Rigual RJ, Viveros OH, Hong JS (1988) Roles of the pituitary-adrenocortical axis in control of the native and cryptic enkephalin levels and proenkephalin mRNA in the sympathoadrenal system of the rat. Mol Brain Res 3:263-274.

Stevens LM, Landis SC (1990) Target influences on transmitter choice by sympathetic neurons developing in the anterior chamber of the eye. Dev Biol 137:109-124.

Stofer WD, Horn JP (1990) Expression of neuropeptide-Y-like immunoreactivity begins after adrenergic differentiation and ganglionic synaptogenesis in developing bullfrog sympathetic neurons. J Neurosci 10:3305-3312.

Stofer WD, Horn JP (1993) Neurogenesis and differentiation of sympathetic B and C cells in the bullfrog tadpole. J Neurosci 13:801-807.

Sun Y, Rao MS, Landis SC, Zigmond RE (1992) Depolarization increases vasoactive intestinal peptide- and substance P-like immunoreactivities in cultured neonatal and adult sympathetic neurons. $J$ Neurosci 12:3717-3728.

Sun Y, Rao M, Zigmond R, Landis S (1994) Regulation of vasoactive intestinal peptide expression in sympathetic neurons in culture and after axotomy: the role of cholinergic/differentiation factor/leukemia inhibitory factor. J Neurobiol, in press.

Symes A, Rao MS, Lewis S, Landis SC, Hyman S, Fink JS (1992) Ciliary neurotrophic factor coordinately activates transcription of neuropeptide genes in a neuroblastoma cell line. Proc Natl Acad Sci USA 90:572-576.

Takahasi M, Ogawa M, Ohta H, Ikeda H (1992) Vasoactive intestinal polypeptide presynaptically enhances the synaptic transmission in cultured sympathetic neurons. Brain Res 579:204-210.

Teillet MA, Cochard P, LeDourain NM (1978) Relative roles of the mesenchymal tissues and of the complex neural tube-notochord on the expression of adrenergic metabolism in neural crest cells. Zoon $6: 115-122$.

Teitelman G, Joh TH, Reis DJ (1978) Transient expression of a noradrenergic phenotype in cells of the rat embryonic gut. Brain Res 158: 229-234.

Teitelman G, Baker H, Joh TH, Reis DJ (1979) Appearance of catecholamine synthesizing enzymes during development of the rat nervous system: possible role of tissue environment. Proc Natl Acad Sci USA 76:509-513.

Teitelman G, Gershon MD, Rothman TP, Joh TH, Reis DJ (1981) Proliferation and distribution of cells that transiently express a catecholaminergic phenotype during development in mice and rats. Dev Biol 86:348-364.

Tsai SH, Tew JM, Shipley MT (1992) Development of cerebral arterial innervation: synchronous development of neuropeptide Y (NPY)and vasoactive intestinal polypeptide (VIP)-containing fibers and some observations on growth cones. Dev Brain Res 69:77-83.

Tyrrell S, Landis SC (1994) Alteration in enkephalin expression by sympathetic neurons following interruption of target contact. J Neurosci, in press.

Tyrrell S, Siegel RE, Landis SC (1992) Tyrosine hydroxylase and neuropeptide $\mathrm{Y}$ expression is increased in sympathectomized rats. Neuroscience 47:985-998.

Vandenbergh DJ, Mori N, Anderson DJ (1991) Co-expression of multiple neurotransmitter enzyme genes in normal and immortalized sympathoadrenal progenitor cells. Dev Biol 148:10-22.

Voyvodic JT (1987) Development and regulation of dendrites in the rat superior cervical ganglion. J Neurosci 7:904-912.

Walker P, Grouzmann E, Burnier M, Waeber B (1991) The role of neuropeptide $\mathrm{Y}$ in cardiovascular regulation. Trends Pharmacol Sci 12:111-115.

Watanabe M, Yanaihara N, Kondo H (1991) Partial down-regulation at post-transcriptional level of the gene expression for preproenkephalin in the superior cervical ganglion of the maturing rat. Dev Brain Res 59:113-116.

Wong V, Kessler JA (1987) Solubilization of a membrane factor that stimulates levels of substance $\mathbf{P}$ and choline acetyltransferase in sympathetic neurons. Proc Natl Acad Sci USA 84:8726-8729.

Yamamori T (1991) Localization of cholinergic differentiation factor/ leukemia inhibitory factor mRNA in the rat brain and peripheral tissues. Proc Natl Acad Sci USA 88:7298-7302.

Zigmond RE, Hyatt-Sachs H, Baldwin C, Qu XM, McKeon TW, Schreiber RC, Vaidyanathan U (1992) Phenotypic plasticity in adult sympathetic neurons: changes in neuropeptide expression in organ culture. Proc Natl Acad Sci USA 89:1507-1511. 